\title{
110th Anniversary: The First Thermodynamic and Kinetic Analysis of Ammonia in Imidazolium-Based Ionic Liquids Using a Gravimetric Microbalance
}

\author{
Tugba Turnaoglu ${ }^{\dagger, \S(0)}$ and Mark B. Shiflett ${ }^{*} \dagger, \ddagger, \S(0)$ \\ ${ }^{\dagger}$ University of Kansas, Department of Chemical and Petroleum Engineering, 1530 West 15th, Lawrence, Kansas 66045, United \\ States \\ ${ }^{\ddagger}$ University of Kansas, Center for Environmentally Beneficial Catalysis, Lawrence, Kansas 66045, United States
}

Supporting Information

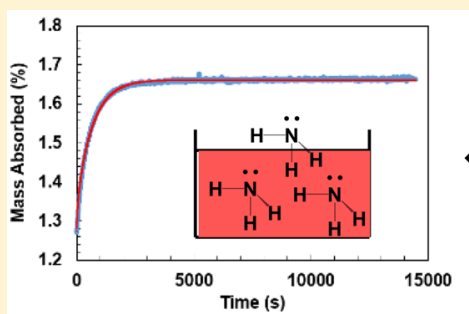

Kinetic Measurement

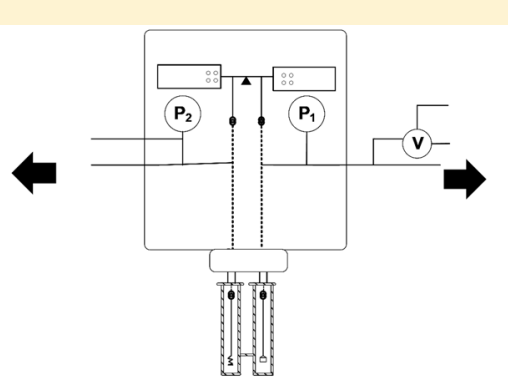

Gravimetric Microbalance

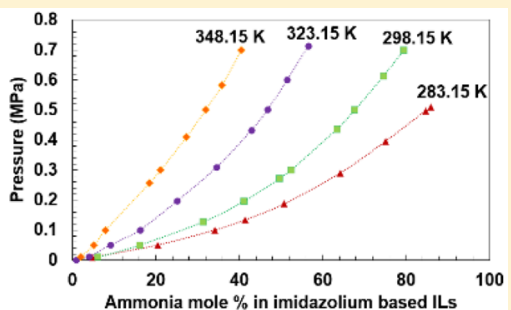

Thermodynamic Measurement

ABSTRACT: The first vapor liquid equilibrium (VLE) measurements for the binary systems of ammonia $\left(\mathrm{NH}_{3}\right)$ and three imidazolium-based ionic liquids (ILs) have been successfully measured using a gravimetric microbalance. ILs 1-butyl-3methylimidazolium hexafluorophosphate $\left(\left[\mathrm{C}_{4} \mathrm{C}_{1} \mathrm{im}\right]\left[\mathrm{PF}_{6}\right]\right)$, 1-butyl-3-methylimidazolium tetrafluoroborate $\left(\left[\mathrm{C}_{4} \mathrm{C}_{1} \mathrm{im}\right]\left[\mathrm{BF}_{4}\right]\right)$, and 1-ethyl-3-methylimidazolium bis(trifluoromethylsulfonyl)imide $\left(\left[\mathrm{C}_{2} \mathrm{C}_{1} \mathrm{im}\right]\left[\mathrm{NTf}_{2}\right]\right)$ were measured at temperatures of 283.15, 298.15, 323.15, and 348.15 K and at pressures up to 0.7 MPa using the new Hiden XEMIS gravimetric microbalance. The VLE data were correlated using the Peng-Robinson equation of state and the Non-Random Two Liquid (NRTL) activity coefficient models. Both models are in excellent agreement with the experimental data. The Fickian diffusivities of $\mathrm{NH}_{3}$ in imidazolium-based ILs were obtained fitting experimental concentration to the one-dimensional (1D) mass diffusion equation, and found to be about 3 to 5 times lower than the diffusion of $\mathrm{NH}_{3}$ in water $\left(\mathrm{H}_{2} \mathrm{O}\right)$. The semitheoretical Stokes-Einstein equation was used to model diffusivities and to obtain the diffusing radius of $\mathrm{NH}_{3}$ in imidazolium-based ILs.

\section{INTRODUCTION}

Ionic liquids (ILs) are liquid salts composed entirely of ions ${ }^{1}$ and defined to have a melting point below $373 \mathrm{~K}$. ILs differ from traditional salts because the charge delocalization, the size of the ion, and/or the ion asymmetry prevent the formation of stable crystals. ${ }^{1}$ This unique behavior for ILs categorizes them as a new class of material with many unique properties such as low vapor pressure, good electrochemical and thermal stability, and high solvation capability. Novel characteristics of ILs have led to extensive research to explore the feasibility of ILs in various applications such as gas separation, absorptionrefrigeration, and catalysis which requires fundamental thermodynamic knowledge (e.g., vapor liquid equilibria) for ILs with other substances. ${ }^{2}$

Ammonia $\left(\mathrm{NH}_{3}\right)$ is one of the most important and largest volume industrial chemicals produced today. Most of the research involving $\mathrm{NH}_{3}$ and ILs has been directed at reducing $\mathrm{NH}_{3}$ emissions or to improve the $\mathrm{NH}_{3}-\mathrm{H}_{2} \mathrm{O}$ absorptionrefrigeration cycle. In 2007, Yokozeki and Shiflett pioneered the investigation of $\mathrm{NH}_{3}$ and $\mathrm{IL}$ mixtures by measuring the
$\mathrm{NH}_{3}$ solubility in eight imidazolium-based ILs suggesting that $\mathrm{NH}_{3}+\mathrm{IL}$ might be an alternative refrigerant-absorbent pair for the $\mathrm{NH}_{3}-\mathrm{H}_{2} \mathrm{O}$ absorption refrigeration cycle. ${ }^{3,4}$ Huang et al. showed the solubility of $\mathrm{NH}_{3}$ in guanidinium-based ILs was comparable with that of imidazolium-based ILs and suggested the interactions between $\mathrm{NH}_{3}$ and the IL were dominated by the cation. ${ }^{5}$ Shi and Maginn using Monte Carlo simulations showed that the basic nitrogen of $\mathrm{NH}_{3}$ associates with the acidic hydrogen that is attached to the $\mathrm{C}(2)$ carbon of the imidazolium ring and the anion has little effect on the solubility of $\mathrm{NH}_{3}$ for $\left[\mathrm{C}_{2} \mathrm{C}_{1} \mathrm{im}\right]\left[\mathrm{NTf}_{2}\right]$. $^{6} \mathrm{Li}$ et al. also found the length of the alkyl chain has an impact on $\mathrm{NH}_{3}$ sorption in imidazoliumbased ILs. For example, the $\mathrm{NH}_{3}$ solubility in imidazolium ILs increased with longer alkyl chains on the cation $\left(\left[\mathrm{C}_{n} \mathrm{C}_{1} \mathrm{im}\right]\right.$ $\left.\left[\mathrm{BF}_{4}\right], n=2,4,6,8\right){ }^{7}$ Tomida et al. recently measured the

Received: January 15, 2019

Revised: February 21, 2019

Accepted: February 25, 2019

Published: February 25, 2019 
solubility of $\mathrm{NH}_{3}$ in $\left[\mathrm{C}_{4} \mathrm{C}_{1} \mathrm{im}\right]\left[\mathrm{PF}_{6}\right]$ over a wide temperature range $(283.15$ to $363.15 \mathrm{~K})$ and at pressures up to $3 \mathrm{MPa}^{8}$

The $\mathrm{NH}_{3}$ absorption capacity was also measured in various hydroxyl functionalized ILs: $\left[\mathrm{N}_{111} \mathrm{C}_{2} \mathrm{OH}\right]\left[\mathrm{NTf}_{2}\right],{ }^{9-11}$ $\left[\left(\mathrm{HOC}_{2}\right) \mathrm{C}_{1} \mathrm{im}\right]\left[\mathrm{BF}_{4}\right],{ }^{9-12} \quad\left[\left(\mathrm{HOC}_{2}\right) \mathrm{C}_{1} \mathrm{im}\right][\mathrm{DCA}],{ }^{10}$ $\left[\mathrm{N}_{1}\left(\mathrm{C}_{2} \mathrm{OH}\right)_{3}\right]\left[\mathrm{C}_{1} \mathrm{OSO}_{3}\right],{ }^{10}$ and $\left[\left(\mathrm{HOC}_{2}\right) \mathrm{C}_{1} \mathrm{im}\right]\left[\mathrm{NTf}_{2}\right]{ }^{11}$ Palomar et al. showed the hydroxyl functionalized cations $\left(\left[\left(\mathrm{HOC}_{2}\right) \mathrm{C}_{1} \mathrm{im}\right]\right.$ or $\left.\left[\mathrm{N}_{111} \mathrm{C}_{2} \mathrm{OH}\right]\right)$ with fluorinated anions enhance the solubility compared to nonfunctionalized analogs. ${ }^{9} \mathrm{Li}$ et al. also reported that the $\mathrm{NH}_{3}$ absorption capacity for hydroxyl functionalized ILs $\left(\left(\left[\left(\mathrm{HOC}_{2}\right) \mathrm{C}_{1} \mathrm{im}\right][\mathrm{X}]\right.\right.$ $\left(\mathrm{X}=\mathrm{PF}_{6}, \mathrm{BF}_{4}, \mathrm{DCA}, \mathrm{SCN}, \mathrm{NO}_{3}\right)$ with any given anion was larger compared to the traditional imidazolium-based counterparts $\left(\left[\mathrm{C}_{2} \mathrm{C}_{1} \mathrm{im}\right][\mathrm{X}]\left(\mathrm{X}=\mathrm{NTf}_{2}, \mathrm{BF}_{4}, \mathrm{NO}_{3}\right)\right) .{ }^{12}$ In addition, they also found that ILs with fluorine-containing anions have a higher $\mathrm{NH}_{3}$ solubility compared with nonfluorinated anions with hydroxyl-containing cations. ${ }^{12}$ However, the hydroxyl group on the imidazolium cation led to an increase in viscosity and consequently a longer time to reach equilibrium. ${ }^{12}$

Metal-ion-containing ILs $\left(\left[\mathrm{C}_{4} \mathrm{C}_{1} \mathrm{im}\right] \mathrm{Zn}_{2} \mathrm{Cl}_{5}{ }^{13}\right.$ and $\left[\mathrm{C}_{2} \mathrm{C}_{1} \mathrm{im}\right] \mathrm{Cu}_{2} \mathrm{Cl}_{5}{ }^{14}$ ) were also investigated to improve $\mathrm{NH}_{3}$ absorption and to overcome issues with using the metal chloride $/ \mathrm{NH}_{3}$ adsorption system. The metal-ion-containing ILs have shown the highest amount of $\mathrm{NH}_{3}$ absorption to date.

In addition to aprotic ILs, protic ILs have also been studied. ${ }^{15,16}$ Shang et al. showed the protic IL $\left[\mathrm{C}_{4} \mathrm{im}\right]\left[\mathrm{NTf}_{2}\right]$ had higher $\mathrm{NH}_{3}$ solubility compared to traditional imidazolium-based ILs such as $\left[\mathrm{C}_{4} \mathrm{C}_{1} \mathrm{im}\right]\left[\mathrm{NTf}_{2}\right]$ or functionalized ILs such as $\left[\left(\mathrm{HOOCC}_{3}\right) \mathrm{C}_{1} \mathrm{im}\right]\left[\mathrm{NTf}_{2}\right] .{ }^{15}$ Also, contrary to aprotic ILs, the cation chain length for protic ILs was found to have little effect on the $\mathrm{NH}_{3}$ solubility; however, fluorinated anions such as $\left[\mathrm{NTf}_{2}\right]$ had higher $\mathrm{NH}_{3}$ absorption compared to nonfluorinated anions $[\mathrm{SCN}]$ and $\left[\mathrm{NO}_{3}\right]^{16}$

Thermodynamic models such as the Redlich-Kwong cubic equation of state $(\mathrm{EoS}),{ }^{3,4}$ Flory-Huggins model, ${ }^{17}$ van der Waals EoS, ${ }^{18}$ Peng-Robinson EoS with Kwak and Mansoori mixing rule (PR/KM), ${ }^{19}$ Artificial Neural Networks method (AAN) ${ }^{20}$ modified UNIFAC model, ${ }^{13,14}$ UNIFAC model, ${ }^{21}$ COSMO-based process simulation with Aspen Plus/Aspen HYSY, $^{22}$ Non-Random Two Liquids (NRTL) model, ${ }^{11}$ and Antoine equation ${ }^{8}$ have been used to correlate experimental VLE data for $\mathrm{NH}_{3}+\mathrm{IL}$ mixtures.

Traditional aprotic ILs (i.e., imidazolium-based ILs) have shown relatively low affinity for $\mathrm{NH}_{3}$ compared to functionalized ILs, metal containing ILs, and protic ILs. However, the latter suffer from a few major drawbacks. For example, hydroxyl functionalized ILs have higher viscosities, metal containing ILs chemically interact/react with $\mathrm{NH}_{3}$, and protic ILs are not stable even at room temperature. Therefore, traditional aprotic ILs are still preferable based on reversible $\mathrm{NH}_{3}$ sorption, lower viscosity, good thermal stability, and lower cost.

The need for accurate thermodynamic and kinetic analysis of $\mathrm{NH}_{3}$ in ILs is essential for developing existing and new applications. Up to now, thermodynamic measurements for $\mathrm{NH}_{3}$ in ILs have been conducted using either volumetric or semigravimetric methods. To the best of our knowledge, the gravimetric method described in this work which is one of the most accurate techniques for measuring gas solubility ${ }^{23}$ has not been previously utilized to measure the solubility of $\mathrm{NH}_{3}$ in ILs because $\mathrm{NH}_{3}$ would permanently damage the balance components. However, the development of the new Hiden XEMIS balance utilizes magnetic coupling to prevent the contact of the gas with the balance electronics so that measurements with $\mathrm{NH}_{3}$ and other corrosive gases are now possible. ${ }^{23}$ In addition to thermodynamic analysis, the XEMIS gravimetric microbalance allows simultaneous time dependent analysis to analyze the kinetics of the dissolution process. Only Bedia et al. have reported the effective diffusivity of $\mathrm{NH}_{3}$ in one imidazolium and four functionalized ILs ${ }^{10}$ using our kinetics model we previously developed for $\mathrm{CO}_{2}+\mathrm{IL}$ mixtures. ${ }^{24}$ Therefore, in this study, the solubility and diffusivity of $\mathrm{NH}_{3}$ in $\left[\mathrm{C}_{4} \mathrm{C}_{1} \mathrm{im}\right]\left[\mathrm{PF}_{6}\right], \quad\left[\mathrm{C}_{4} \mathrm{C}_{1} \mathrm{im}\right]\left[\mathrm{BF}_{4}\right]$, and $\left[\mathrm{C}_{2} \mathrm{C}_{1} \mathrm{im}\right]\left[\mathrm{NTf}_{2}\right]$ ILs were analyzed using the gravimetric method at pressures up to $0.7 \mathrm{MPa}$ and at temperatures of $283.15,298.15,323.15$, and $348.15 \mathrm{~K}$. The accuracy of the experimental method was thoroughly assessed by measuring the solubility of $\mathrm{CO}_{2}$ in 1hexyl-3-methylimidazolium bis(trifluoromethylsulfonyl)imide $\left(\left[\mathrm{C}_{6} \mathrm{C}_{1} \mathrm{im}\right]\left[\mathrm{NTf}_{2}\right]\right)$ and compared with the benchmark study developed and sponsored by the International Union of Pure and Applied Chemistry (IUPAC) for the same binary system. Experimental vapor-liquid-equilibria data were modeled using two approaches: (1) liquid and vapor phase are modeled with the Peng-Robinson EoS, and (2) liquid phase was modeled with an activity coefficient model and the vapor phase fugacity was corrected using the second virial coefficient. In addition to thermodynamics of $\mathrm{NH}_{3}+\mathrm{IL}$ mixtures, the timedependent behavior of $\mathrm{NH}_{3}$ absorption in $\left[\mathrm{C}_{4} \mathrm{C}_{1} \mathrm{im}\right]\left[\mathrm{PF}_{6}\right]$, $\left[\mathrm{C}_{4} \mathrm{C}_{1} \mathrm{im}\right]\left[\mathrm{BF}_{4}\right]$, and $\left[\mathrm{C}_{2} \mathrm{C}_{1} \mathrm{im}\right]\left[\mathrm{NTf}_{2}\right]$ were analyzed using the one-dimensional (1D) mass transfer equation and a semitheoretical Einstein-Stokes equation where the diffusing radius for $\mathrm{NH}_{3}$ in the mixtures was also reported.

\section{EXPERIMENTAL SECTION}

2.1. Materials. High purity anhydrous $\mathrm{NH}_{3}$ (purity of $\geq 99.9992 \%$, CAS No. 7664-41-7) and research grade carbon dioxide (purity of $99.999 \%$, CAS No. 124-38-9) were obtained from Matheson Tri-Gas, Inc. (Topeka, KS). The ILs $\left[\mathrm{C}_{6} \mathrm{C}_{1} \mathrm{im}\right]\left[\mathrm{NTf}_{2}\right]$ (assay $>99 \%$, CAS No. 382150-50-7, Lot No. EQ500831 632), $\left[\mathrm{C}_{4} \mathrm{C}_{1} \mathrm{im}\right]\left[\mathrm{PF}_{6}\right]$ (assay $\geq 96 \%$, CAS No. 174501-64-5, Lot and Filling Code No. 1242554 304070904), $\left[\mathrm{C}_{4} \mathrm{C}_{1} \mathrm{im}\right]\left[\mathrm{BF}_{4}\right]$ (assay, $\geq 97 \%$, CAS No. 174501-65-6, Lot and Filling Code No. 111628023404335$)$, and $\left[\mathrm{C}_{2} \mathrm{C}_{1} \mathrm{im}\right]\left[\mathrm{NTf}_{2}\right]$ (assay 99\%, CAS No. 174899-90-2, IL-0023-HP-1000 H00620.1) were obtained from EMD Chemicals, Inc. (U.S.), Fluka (Switzerland), Fluka (Germany), and IoLiTec, Inc. (Germany), respectively. The chemical structures for the imidazolium-based ILs are provided in Table S1 (see Supporting Information). The ILs were stored under nitrogen to prevent moisture contamination. The as-received ILs were dried under vacuum before conducting gas solubility measurements. To account for buoyancy effects in the experimental method (see Supporting Information), the gas density as a function of $T$ and $P$ as well as the liquid density of the pure ILs as a function of $T$ are required. The density of $\mathrm{NH}_{3}$ and $\mathrm{CO}_{2}$ were obtained using the National Institute of Standards and Technology (NIST) REFPROP V.9.1 database. ${ }^{25}$ The density of $\left[\mathrm{C}_{6} \mathrm{C}_{1} \mathrm{im}\right]\left[\mathrm{NTf}_{2}\right]$ was calculated using the recommended IUPAC correlation. ${ }^{26}$ The density of $\left[\mathrm{C}_{4} \mathrm{C}_{1} \mathrm{im}\right]\left[\mathrm{PF}_{6}\right]$, $\left[\mathrm{C}_{4} \mathrm{C}_{1} \mathrm{im}\right]\left[\mathrm{BF}_{4}\right]$, and $\left[\mathrm{C}_{2} \mathrm{C}_{1} \mathrm{im}\right]\left[\mathrm{NTf}_{2}\right]$ were obtained from the literature. ${ }^{27-29}$

2.2. Apparatus and Measurement. The solubility of $\mathrm{NH}_{3}$ in the three ILs was measured using a XEMIS gravimetric microbalance (Hiden Isochema, United Kingdom). The experimental apparatus and procedure have been previously discussed in detail; ${ }^{23}$ therefore, only brief description along 
with measurement uncertainties are provided here. A small amount of IL sample $(\sim 40-60 \mathrm{mg})$ was loaded into a flat bottom Pyrex sample container. The sample was dried and degassed under high vacuum $\left(10^{-12} \mathrm{MPa}\right)$ at $348.15 \mathrm{~K}$ for $24 \mathrm{~h}$ to remove moisture and volatile impurities before each experiment in the balance. The balance was operated in static mode to eliminate drag forces by introducing $\mathrm{NH}_{3}$ to the top of the balance away from the sample and by controlling the setpoint pressure with simultaneous adjustments to the admit and exhaust valves. To ensure sufficient time for thermodynamic equilibrium, the IL sample was maintained at each set point pressure for a minimum of $8 \mathrm{~h}$ to a maximum of $20 \mathrm{~h}$. The sample and counterweight temperatures were measured with a K-type thermocouple with an accuracy of $\pm 0.1 \mathrm{~K}$ and calibrated against a NIST traceable standard platinum resistance thermometer (Hart Scientific SPRT model 5699 and readout Hart Scientific Blackstack model 1560 with a SPRT module 2560). The Blackstack instrument and SPRT module are also a certified secondary temperature standard with a NIST traceable accuracy to $\pm 0.005 \mathrm{~K}$. The XEMIS microbalance is equipped with two pressure transducers. The low-pressure transducer is used up to $2 \mathrm{MPa}$, and the highpressure transducer is used up to $17 \mathrm{MPa}$. The low-pressure transducer can measure pressures as low as 10 to $20 \mathrm{mbar}$ which is useful when fine pressure regulation is required. Both pressure transducers within the XEMIS microbalance were calibrated against a NIST traceable Paroscientific Model 765$1 \mathrm{~K}$ pressure transducer (range 0 to $6.89 \mathrm{MPa}$, serial no. 101314). This instrument is a NIST-certified secondary pressure standard with a traceable accuracy of $\pm 0.0008 \mathrm{MPa}$. The instrumental uncertainty in $T$ is within $\pm 0.1 \mathrm{~K}$, and $P$ is within $\pm 0.0001 \mathrm{MPa}$ for the low-pressure transducer and $\pm 0.001 \mathrm{MPa}$ for the high-pressure transducer. In this study, $\mathrm{NH}_{3}$ experiments were conducted using the low-pressure transducer due to the required fine pressure control at low pressures. However, the XEMIS system with both low- and high-pressure transducers was thoroughly evaluated using the $\mathrm{CO}_{2}+\left[\mathrm{C}_{6} \mathrm{C}_{1} \mathrm{im}\right]\left[\mathrm{NTf}_{2}\right]$ reference system described in the IUPAC study. ${ }^{26}$ The gas sorption data were corrected for buoyancy and volume expansion using the procedure described in the Supporting Information (Appendix 1). The total uncertainties in the solubility data have been estimated to be less than $\pm 0.5 \mathrm{~mol} \%$ at any given $T$ and $P$.

2.3. Safety. Ammonia must be handled with extreme caution as it is both a combustible and highly toxic gas. In our laboratory, numerous safety features have been implemented to safely handle $\mathrm{NH}_{3}{ }^{30}$ First, the microbalance and temperature/pressure/vacuum control system are located in a specially designed ventilated enclosure which offers protection in the event of an $\mathrm{NH}_{3}$ leak. The ventilated enclosure is equipped with a fire sprinkler and a safety interlock system. The interlock system is connected to an emergency crash button outside the enclosure, a photohelic for measuring the ventilation flow rate, and two $\mathrm{NH}_{3}$ gas monitors (3M Scott Safety, Freedom 5000, Serial 3568 with $\mathrm{NH}_{3}$ sensor, 096-19650100 and 3M Scott Safety, Meridian Universal Gas Detector, Model 096-3480-01 with $\mathrm{NH}_{3}$ sensor 096-3473-03). In the event that the crash button is depressed, a loss of ventilation occurs, or either gas monitor detects an $\mathrm{NH}_{3}$ leak, an air-toopen (ATO) valve on the $\mathrm{NH}_{3}$ feed line will automatically close and shutoff the $\mathrm{NH}_{3}$ source. One $\mathrm{NH}_{3}$ monitor is located inside the enclosure and the other $\mathrm{NH}_{3}$ monitor is located outside the enclosure. Both $\mathrm{NH}_{3}$ monitors are calibrated and tested quarterly to ensure proper operation. Two alarms were set for alert at $25 \mathrm{ppm}\left(50 \%\right.$ of $\mathrm{NH}_{3}$ allowable exposure limit (AEL)) and warning at $15 \mathrm{ppm}\left(30 \% \mathrm{NH}_{3} \mathrm{AEL}\right)$. In addition, to the ATO valve closing, yellow and red warning lights flash and a siren sounds in the lab for alert and warning alarms, respectively. A data acquisition system (Yokogawa, Model GM10 with Power Supply, Model GM90PS and Module Base, Model GM90MB) provides text and email messages to inform researchers when the $\mathrm{NH}_{3}$ detector activates or loss of ventilation occurs. Nitrogen gas is setup to purge $\mathrm{NH}_{3}$ lines and the microbalance (three times) before opening the system. A Research Hazard Review (RHR) was carefully conducted to evaluate and document all hazards including unattended operation, and only authorized operators are allowed to use the equipment. The RHR analysis, procedures, and equipment have demonstrated that the XEMIS microbalance can be safely operated using flammable and toxic gases such as $\mathrm{NH}_{3}$.

\section{RESULTS AND DISCUSSION}

3.1. Assessment of Experimental Method. The accuracy of the XEMIS microbalance was assessed by measuring the solubility of $\mathrm{CO}_{2}$ in $\left[\mathrm{C}_{6} \mathrm{C}_{1} \mathrm{im}\right]\left[\mathrm{NTf}_{2}\right]$ which is a standard measurement recommended by the IUPAC in 2007. ${ }^{26}$ The experimental data obtained in this work were compared with the values reported in the IUPAC study by Shiflett et al. ${ }^{31}$ and Kumelan et al. ${ }^{32}$ which are both in good agreement. The solubility of $\mathrm{CO}_{2}$ in $\left[\mathrm{C}_{6} \mathrm{C}_{1} \mathrm{im}\right]\left[\mathrm{NTf}_{2}\right]$ was measured using the high-pressure transducer at pressures from 0.1 to $5 \mathrm{MPa}$, and using the low pressure transducer at pressures from 0.01 to $2 \mathrm{MPa}$. At low pressures, the data showed an average deviation of less than $0.5 \mathrm{~mol} \%$ compared to Shiflett et al. ${ }^{31}$ At high pressures, the data showed an average deviation of $0.3 \mathrm{~mol} \%$ compared to Kumelan et al. ${ }^{32}$ The results indicate that the XEMIS gravimetric microbalance is a highly accurate and reliable experimental method for gas solubility measurements in ILs.

The solubility of $\mathrm{NH}_{3}$ in $\left[\mathrm{C}_{4} \mathrm{C}_{1} \mathrm{im}\right]\left[\mathrm{BF}_{4}\right]$ at $293.15 \mathrm{~K}$ and at pressures up to $0.5 \mathrm{MPa}$ was selected as a reference system to validate the accuracy of the experimental techniques in the literature. Figure 1 shows this study is in good agreement with

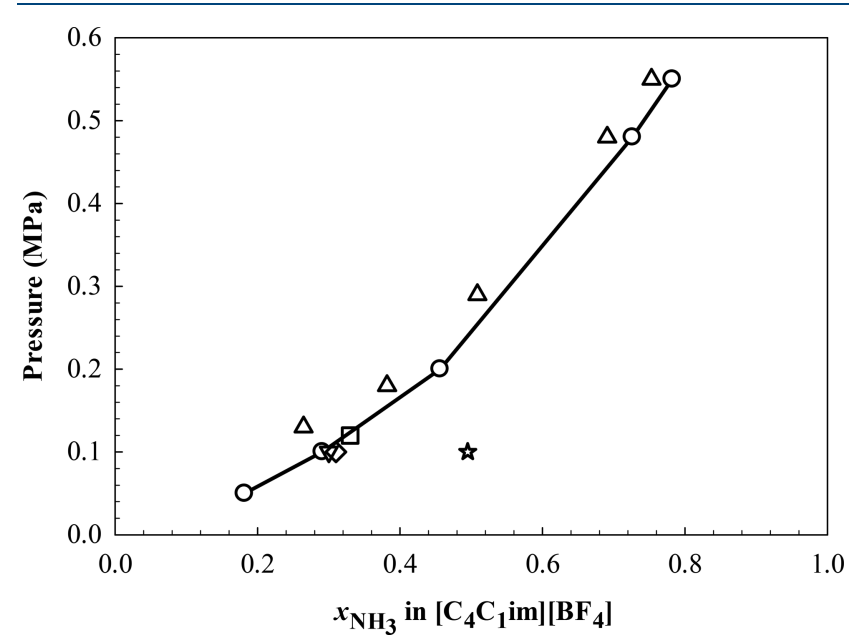

Figure 1. Comparison of the experimental PTx diagram of $\mathrm{NH}_{3}$ solubility in $\left[\mathrm{C}_{4} \mathrm{C}_{1} \mathrm{im}\right]\left[\mathrm{BF}_{4}\right]$ at $293.15 \mathrm{~K}$. Symbols: (O) this study; $(\Delta)$ Li et al.; $(\diamond)$ Bedia et al.; ${ }^{10}(\nabla)$ Palomar et al. ${ }^{9}(\square)$ Shang et al.; ${ }^{15}$ (₹) Huang et al..$^{5}$ Solid line added to guide the eye. 
Table 1. Henry's Law Constants for the Mixtures of $\mathrm{NH}_{3}+\left[\mathrm{C}_{4} \mathrm{C}_{1} \mathrm{im}\right]\left[\mathrm{PF}_{6}\right], \mathrm{NH}_{3}+\left[\mathrm{C}_{4} \mathrm{C}_{1} \mathrm{im}^{\mathrm{im}}\right]\left[\mathrm{BF}_{4}\right]$, and $\mathrm{NH}_{3}+$ $\left[\mathrm{C}_{2} \mathrm{C}_{1} \mathrm{im}\right]\left[\mathrm{NTf}_{2}\right]$ at $283.15,298.15,323.15$, and $348.15 \mathrm{~K}$

\begin{tabular}{ccccc} 
& \multicolumn{4}{c}{ Henry's law constants, $k_{\mathrm{H}}(\mathrm{MPa})^{a}$} \\
\cline { 2 - 5 } Binary System & $T=283.15 \mathrm{~K}$ & $T=298.15 \mathrm{~K}$ & $T=323.15 \mathrm{~K}$ & $T=348.15 \mathrm{~K}$ \\
$\mathrm{NH}_{3}+\left[\mathrm{C}_{4} \mathrm{C}_{1} \mathrm{im}\right]\left[\mathrm{PF}_{6}\right]$ & $0.31 \pm 0.02$ & $0.46 \pm 0.03$ & $0.83 \pm 0.03$ & $1.4 \pm 0.16$ \\
$\mathrm{NH}_{3}+\left[\mathrm{C}_{4} \mathrm{C}_{1} \mathrm{im}\right]\left[\mathrm{BF}_{4}\right]$ & $0.29 \pm 0.02$ & $0.41 \pm 0.04$ & $0.64 \pm 0.07$ & $1.3 \pm 0.17$ \\
$\mathrm{NH}_{3}+\left[\mathrm{C}_{2} \mathrm{C}_{1} \mathrm{im}\right]\left[\mathrm{NTf}_{2}\right]$ & $0.31 \pm 0.02$ & $0.46 \pm 0.03$ & $0.81 \pm 0.04$ & $1.1 \pm 0.14$
\end{tabular}

${ }^{a_{T}}$ The uncertainties are the standard error of the coefficient obtained in the linear regression.

Palomar et al., ${ }^{9}$ Bedia et al., ${ }^{10}$ and Shang et al. ${ }^{15}$ with a deviation of less than $2 \mathrm{~mol} \%$. The deviation in the data of $\mathrm{Li}$ et al. ${ }^{7}$ and Huang et al. ${ }^{5}$ may be due to improper calibration, high relative uncertainty in their given experimental procedure, or the presence of water and/or other impurities in the ILs.

3.2. Vapor Liquid Equilibria Measurement and Thermodynamic Modeling. The solubility of $\mathrm{NH}_{3}$ in $\left[\mathrm{C}_{4} \mathrm{C}_{1} \mathrm{im}\right]\left[\mathrm{PF}_{6}\right], \quad\left[\mathrm{C}_{4} \mathrm{C}_{1} \mathrm{im}\right]\left[\mathrm{BF}_{4}\right]$, and $\left[\mathrm{C}_{2} \mathrm{C}_{1} \mathrm{im}\right]\left[\mathrm{NTf}_{2}\right]$ was measured at temperatures of 283.15, 298.15, 323.15, and $348.15 \mathrm{~K}$ and pressures ranging from 0.010 to $0.7 \mathrm{MPa}$. The present experimental solubility $(P T x)$ data are summarized in Tables S2-S4 (see Supporting Information). Yokozeki and Shiflett previously demonstrated high $\mathrm{NH}_{3}$ sorption in $\left[\mathrm{C}_{4} \mathrm{C}_{1} \mathrm{im}\right]\left[\mathrm{PF}_{6}\right],\left[\mathrm{C}_{4} \mathrm{C}_{1} \mathrm{im}\right]\left[\mathrm{BF}_{4}\right]$, and $\left[\mathrm{C}_{2} \mathrm{C}_{1} \mathrm{im}\right]\left[\mathrm{NTf}_{2}\right]$; however, the inaccuracy due to weighing small amounts of $\mathrm{NH}_{3}$ using a semigravimetric method resulted in large uncertainties in compositions, especially at low $\mathrm{NH}_{3}$ concentrations (i.e., low pressures). ${ }^{3}$ The comparison of the results in this study and our previous results (Figure $\mathrm{S} 1$ in the Supporting Information) indicates that the $\mathrm{NH}_{3}$ solubility in these ILs was originally underestimated particularly at low pressures. As described in Section 3.1, the XEMIS balance provides highly accurate solubility measurements even at low pressures (e.g., 10 mbar). Therefore, this study reports the most accurate vapor liquid equilibria data for mixtures of $\mathrm{NH}_{3}$ and $\left[\mathrm{C}_{4} \mathrm{C}_{1} \mathrm{im}\right]\left[\mathrm{PF}_{6}\right], \mathrm{NH}_{3}$ and $\left[\mathrm{C}_{4} \mathrm{C}_{1} \mathrm{im}\right]\left[\mathrm{BF}_{4}\right]$, and $\mathrm{NH}_{3}$ and $\left[\mathrm{C}_{2} \mathrm{C}_{1} \mathrm{im}\right]\left[\mathrm{NTf}_{2}\right]$ at temperatures from 283.15 to $348.15 \mathrm{~K}$ and pressures up to $0.7 \mathrm{MPa}$.

3.2.1. Henry's Law Constants at Infinite Dilution. Henry's law constants $\left(k_{\mathrm{H}}\right)$ are used for assessment of gas solubility in a solvent at dilute concentrations where the lower the $k_{\mathrm{H}}$ value, the higher the gas solubility in the solvent. In this study, the $\mathrm{NH}_{3}$ solubility linearly increases at pressures up to about 0.15 $\mathrm{MPa}$ indicating the Henry's law regime. The results suggest the partial pressure of $\mathrm{NH}_{3}\left(P_{\mathrm{NH}_{3}} \approx P\right.$ as $\left.P_{\mathrm{IL}}{ }^{\text {vap }} \approx 0\right)$ is directly proportional to its liquid phase concentration in the dilute regime. The Henry's law constants can be obtained from experimental gas solubility $(P T x)$ data using the following relation assuming the hydrostatic pressure correction (Krichevsky-Kasarnovsky equation) is not required:

$$
k_{\mathrm{H}}=\lim _{x_{1} \rightarrow 0} \frac{f_{1}^{V}\left(T, P, y_{1}\right)}{x_{1}} \approx\left(\frac{\mathrm{d} f_{1}^{V}}{\mathrm{~d} x_{1}}\right)_{x_{1}=0}
$$

where $f^{V}$ is the vapor phase fugacity of the pure gas $\left(y_{1}=1\right)$ and can be calculated by a proper EOS model at a given condition $(T, P) .^{25}$ The Henry's law constants were obtained calculating the limiting slope while $x_{\mathrm{NH}_{3}}$ approaches zero using the linear fit of experimental data up to $0.15 \mathrm{MPa}$ including a theoretical zero point (zero pressure and zero composition). The Henry's law constants obtained for this study are shown in Table 1. The Henry's law constants increase with an increase in $T$ for the three ILs indicating that the solubility of $\mathrm{NH}_{3}$ decreases with increase in $T$.

The Henry's law constants are also used to estimate the enthalpy $\left(\Delta \bar{H}_{\text {sol }}\right)$ and entropy $\left(\Delta \bar{S}_{\text {sol }}\right)$ of gas dissolution that accompanies the absorption of a mole of gas into a solution at infinite dilution using the thermodynamic van't Hoff relations:

$$
\begin{gathered}
\left(\frac{\partial \ln k_{\mathrm{H}}}{\partial T}\right)_{p}=-\frac{\Delta \bar{H}_{\mathrm{sol}}}{R T^{2}} \\
\left(\frac{\partial \ln k_{\mathrm{H}}}{\partial T}\right)_{p}=-\frac{\Delta \bar{S}_{\mathrm{sol}}}{R T}
\end{gathered}
$$

The $\Delta \bar{H}_{\text {sol }}$ and $\Delta \bar{S}_{\text {sol }}$ can be obtained by calculating the slope from eqs 2 and 3 and using the Henry's law constants provided in Table 1. The $\Delta \bar{H}_{\text {sol }}$ and $\Delta \bar{S}_{\text {sol }}$ of $\mathrm{NH}_{3}$ absorption in $\left[\mathrm{C}_{4} \mathrm{C}_{1} \mathrm{im}\right]\left[\mathrm{PF}_{6}\right], \quad\left[\mathrm{C}_{4} \mathrm{C}_{1} \mathrm{im}\right]\left[\mathrm{BF}_{4}\right]$, and $\left[\mathrm{C}_{2} \mathrm{C}_{1} \mathrm{im}\right]\left[\mathrm{NTf}_{2}\right]$ are reported in Table 2. The negative $\Delta \bar{H}_{\text {sol }}$ indicates the $\mathrm{NH}_{3}$

Table 2. Enthalpy of Solution $\left(\Delta \overline{\boldsymbol{H}}_{\text {sol }}\right)$ and Entropy of Solution $\left(\Delta \bar{S}_{s o l}\right)$ of $\mathrm{NH}_{3}$ Absorption in $\left[\mathrm{C}_{4} \mathrm{C}_{1} \mathrm{im}\right]\left[\mathrm{PF}_{6}\right]$, $\left[\mathrm{C}_{4} \mathrm{C}_{1} \mathrm{im}\right]\left[\mathrm{BF}_{4}\right]$, and $\left[\mathrm{C}_{2} \mathrm{C}_{1} \mathrm{im}\right]\left[\mathrm{NTf}_{2}\right]$ at Infinite Dilution

$\begin{array}{ccc}\text { Ionic Liquid } & \Delta \bar{H}_{\text {sol }}\left(\mathrm{kJ} \cdot \mathrm{mol}^{-1}\right)^{a} & \Delta \overline{\mathrm{S}}_{\text {sol }}\left(\mathrm{J} \cdot \mathrm{mol}^{-1} \cdot \mathrm{K}^{-1}\right)^{a} \\ {\left[\mathrm{C}_{4} \mathrm{C}_{1} \mathrm{im}\right]\left[\mathrm{PF}_{6}\right]} & -18.7 \pm 0.4 & -59.7 \pm 1.7 \\ {\left[\mathrm{C}_{4} \mathrm{C}_{1} \mathrm{im}\right]\left[\mathrm{BF}_{4}\right]} & -18.1 \pm 1.8 & -57.9 \pm 4.6 \\ {\left[\mathrm{C}_{2} \mathrm{C}_{1} \mathrm{im}\right]\left[\mathrm{NTF}_{2}\right]} & -16.1 \pm 1.2 & -51.3 \pm 4.8\end{array}$

${ }^{a}$ The uncertainties are the standard error of the coefficient obtained in the linear regression.

sorption in imidazolium-based ILs is exothermic. Also, the magnitude of $\Delta \bar{H}_{\text {sol }}$ indicates relatively weak association of $\mathrm{NH}_{3}$ in IL which suggests only physical sorption (i.e., gas solubilities) at low $\mathrm{NH}_{3}$ compositions. The negative $\Delta \bar{S}_{\text {sol }}$ indicates $\mathrm{NH}_{3}$ absorption in imidazolium-based ILs increases in molecular ordering. The $\Delta \bar{H}_{\text {sol }}$ and $\Delta \bar{S}_{\text {sol }}$ results are very similar to $\mathrm{SO}_{2}$ in $\left[\mathrm{C}_{4} \mathrm{C}_{1} \mathrm{im}\right]\left[\mathrm{BF}_{4}\right]^{5}$ and $\mathrm{CO}_{2}$ in $\left[\mathrm{C}_{4} \mathrm{C}_{1} \mathrm{im}\right]$ $\left[\mathrm{PF}_{6}\right]^{33}$. This suggests there is no regular bonding between the solvent (ILs) and solute molecules $\left(\mathrm{NH}_{3}, \mathrm{SO}_{2}\right.$, or $\left.\mathrm{CO}_{2}\right)$ at infinite dilution. It is worth emphasizing that the $\Delta \bar{H}_{\text {sol }}$ and $\Delta \bar{S}_{\text {sol }}$ results are only instructive at low $\mathrm{NH}_{3}$ compositions (i.e., below $0.15 \mathrm{MPa}$ ).

3.2.2. Peng-Robinson Equation of State Model. The Peng-Robinson Equation of State (PR-EoS) was selected to model vapor-liquid equilibrium data, as it has been used extensively in academic evaluations and industrial applications ${ }^{34}$ and has been previously applied to $\mathrm{NH}_{3}+\mathrm{IL}$ mixtures. ${ }^{19}$ The PR-EoS is given as: ${ }^{35}$

$$
P=\frac{R T}{\underline{V}-b_{\mathrm{m}}}-\frac{a_{\mathrm{m}}}{\underline{V}\left(\underline{V}-b_{\mathrm{m}}\right)+b\left(\underline{V}-b_{\mathrm{m}}\right)}
$$


where $a_{\mathrm{m}}$ and $b_{\mathrm{m}}$ are the mixture attractive term and co-volume parameters, respectively. The $a_{\mathrm{m}}$ and $b_{\mathrm{m}}$ parameters are computed with the one parameter van der Waals mixing rule with Boston-Mathias extension for the attractive term and the standard PR-EoS alpha function. Pure component parameters $\left(a_{i}\right.$ and $\left.b_{i}\right)$ are computed based on the critical temperature $\left(T_{c}\right)$, critical pressure $\left(P_{c}\right)$, and acentric factor $(\omega)$. The PREoS parameters $\left(a_{i}, b_{i}, \alpha_{i}(T), m, a_{\mathrm{m}}, b_{\mathrm{m}}, k_{i j}\right.$, and $\left.l_{i j}\right)$ used for this analysis are shown in eqs $5-12$. Table 3 provides the EoS

Table 3. Pure Component EoS Constants Used in This Study

\begin{tabular}{lcccc}
\multicolumn{1}{c}{ Compound } & $\begin{array}{c}\text { Molar Mass } \\
\left(\mathrm{g} \cdot \mathrm{mol}^{-1}\right)\end{array}$ & $\begin{array}{c}T_{c} \\
(\mathrm{~K})^{a}\end{array}$ & $\begin{array}{c}P_{c} \\
(\mathrm{MPa})^{a}\end{array}$ & $\omega^{a}$ \\
\hline $\mathrm{NH}_{3}$ & 17.03 & 405.7 & 11.3 & 0.253 \\
{$\left[\mathrm{C}_{4} \mathrm{C}_{1} \mathrm{im}\right]\left[\mathrm{PF}_{6}\right]$} & 284.18 & 708.9 & 1.73 & 0.755 \\
{$\left[\mathrm{C}_{4} \mathrm{C}_{1} \mathrm{im}\right]\left[\mathrm{BF}_{4}\right]$} & 226.03 & 632.3 & 2.04 & 0.849 \\
{$\left[\mathrm{C}_{2} \mathrm{C}_{1} \mathrm{im}\right]\left[\mathrm{NTF}_{2}\right]$} & 391.31 & 1244.9 & 3.26 & 0.182
\end{tabular}

${ }^{a}$ The critical properties and acentric factor of the ILs were taken from ref 37 .

constants used for $\mathrm{NH}_{3}$ and ILs. The binary parameters $k_{i j}$ and $l_{i j}$ were determined from the regression of the VLE data using ASPEN Plus v. $10^{36}$ by minimizing the objective function of the average absolute relative deviation $\left(\% \mathrm{AARD}=(100 / n) \sum_{i=1}^{n} \mathrm{l}\right.$ $\left.\left.\left(P^{\exp }-P^{\text {regressed }}\right) / P^{\exp }\right) \mid\right)$. The results are listed in Table 4 . The

Table 4. Binary Interaction Parameters for the PengRobinson EoS Model

\begin{tabular}{ccccc}
$\mathrm{NH}_{3}-\mathrm{ILs}$ & $\mathrm{Temp}(\mathrm{K})$ & $k_{12}$ & $l_{12}$ & AARD \% \\
$\mathrm{NH}_{3}-\left[\mathrm{C}_{4} \mathrm{C}_{1} \mathrm{im}\right]\left[\mathrm{PF}_{6}\right]$ & 283.15 & -0.1962 & 0.1361 & 4.4 \\
& 298.15 & -0.2090 & 0.0039 & 6.5 \\
& 323.15 & -0.1729 & 0.0914 & 3.4 \\
& 348.15 & -0.0785 & 0.4920 & 3.4 \\
$\mathrm{NH}_{3}-\left[\mathrm{C}_{4} \mathrm{C}_{1} \mathrm{im}\right]\left[\mathrm{BF}_{4}\right]$ & 283.15 & -0.2034 & -0.1648 & 3.3 \\
& 298.15 & -0.2189 & 0.0512 & 2.3 \\
& 323.15 & -0.2084 & 0.1420 & 2.3 \\
& 348.15 & -0.1774 & 0.1300 & 4.0 \\
& & & & \\
$\mathrm{NH}_{3}-\left[\mathrm{C}_{2} \mathrm{C}_{1} \mathrm{im}\right]\left[\mathrm{NTf}_{2}\right]$ & 283.15 & -0.1320 & 0.0520 & 1.9 \\
& 298.15 & -0.1340 & 0.0457 & 1.9 \\
& 323.15 & -0.1345 & 0.0882 & 1.9 \\
& 348.15 & -0.1338 & 0.1694 & 2.9 \\
\hline
\end{tabular}

experimental results along with the PR-EoS models are shown in Figures 2, 3, and 4. The difference between the experimental and estimated VLE data for the three binary mixtures of $\mathrm{NH}_{3}-$ ILs was less than 5\% AARD except in the case of $\mathrm{NH}_{3}+$ $\left[\mathrm{C}_{4} \mathrm{C}_{1} \mathrm{im}\right]\left[\mathrm{PF}_{6}\right]$ at $298.15 \mathrm{~K}$ where the model underestimates the VLE behavior by $6.5 \%$ AARD. The critical properties of the ILs cannot be experimentally determined (i.e., critical temperature is above the decomposition temperature). Therefore, the critical properties used in this study were obtained from the literature where the critical properties were estimated using a Group Contribution Method. ${ }^{37}$ As the ILs have very low vapor pressure, one might expect to observe the $T_{\mathrm{c}}$ of $\left[\mathrm{C}_{4} \mathrm{C}_{1} \mathrm{im}\right]\left[\mathrm{PF}_{6}\right]$ or $\left[\mathrm{C}_{4} \mathrm{C}_{1} \mathrm{im}\right]\left[\mathrm{BF}_{4}\right]$ to be higher than what is reported in Table 3. Therefore, to investigate the impact of $T_{c}$ of the ILs on the PR-EoS fit, the PR-EoS models for the systems $\mathrm{NH}_{3}+$ $\left[\mathrm{C}_{4} \mathrm{C}_{1} \mathrm{im}\right]\left[\mathrm{PF}_{6}\right]$ and $\mathrm{NH}_{3}+\left[\mathrm{C}_{4} \mathrm{C}_{1} \mathrm{im}\right]\left[\mathrm{BF}_{4}\right]$ systems were also

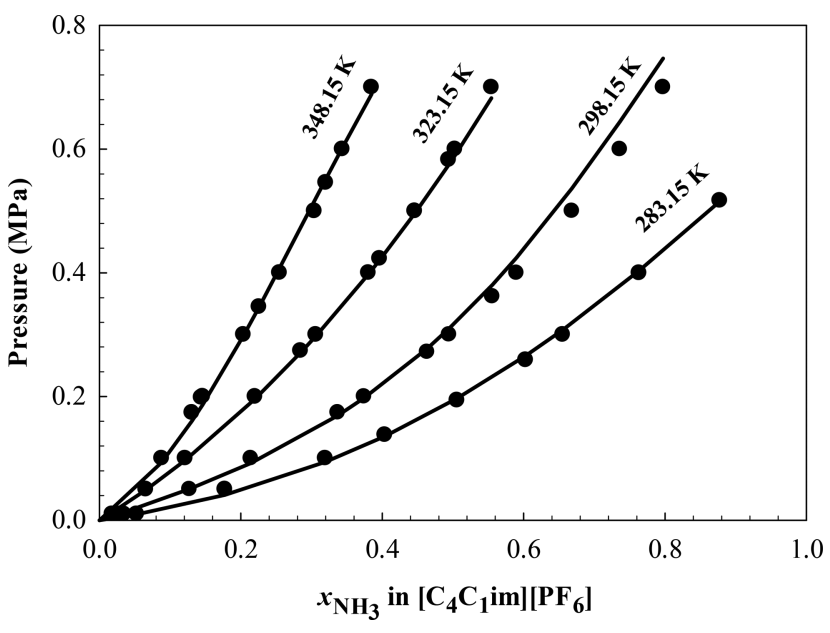

Figure 2. $P T x$ phase diagram for $\mathrm{NH}_{3}$ and $\left[\mathrm{C}_{4} \mathrm{C}_{1} \mathrm{im}\right]\left[\mathrm{PF}_{6}\right]$ at 283.15, 298.15 , 318.15, and 338.15 K. Symbols represent experimental data, and solid lines represents PR-EoS model.

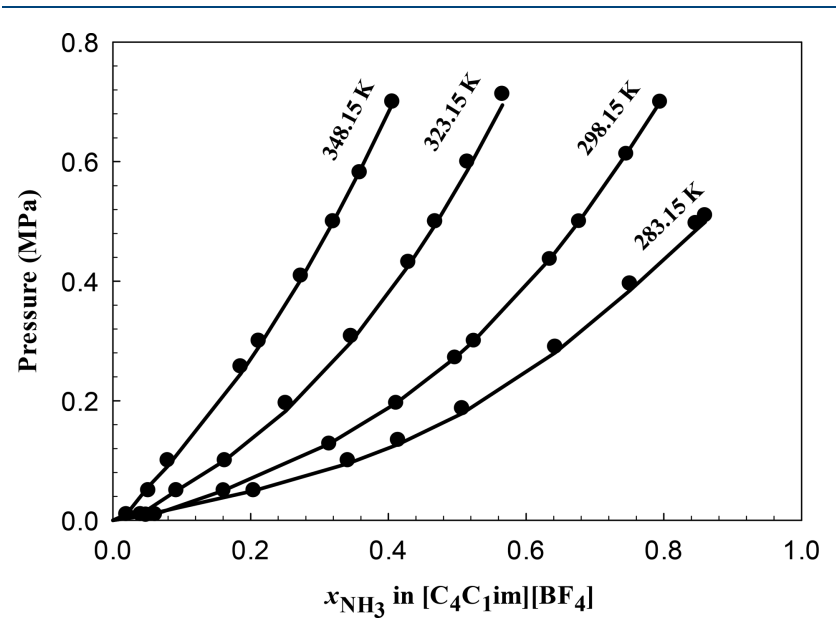

Figure 3. $P T x$ phase diagram for $\mathrm{NH}_{3}$ and $\left[\mathrm{C}_{4} \mathrm{C}_{1} \mathrm{im}\right]\left[\mathrm{BF}_{4}\right]$ at 283.15 , $298.15,318.15$, and $338.15 \mathrm{~K}$. Symbols represent experimental data, and solid lines represents PR-EoS model.

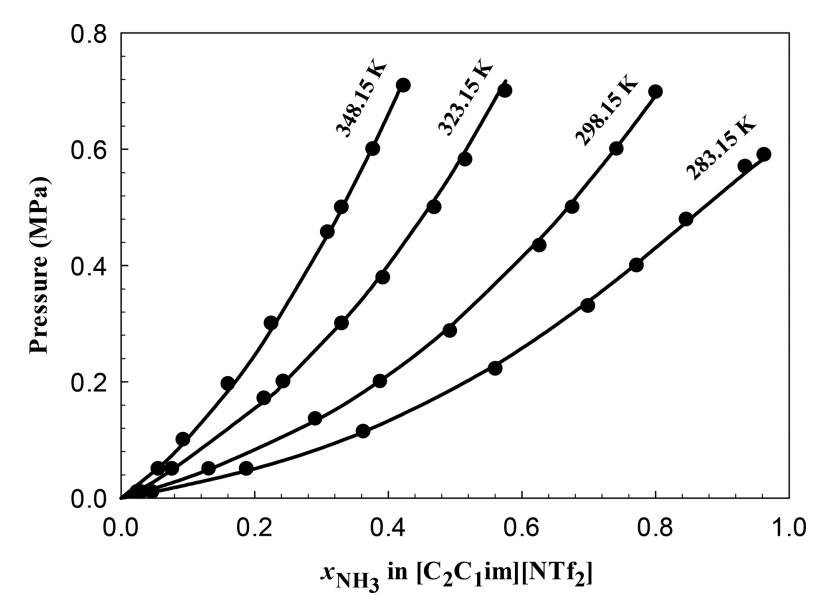

Figure 4. $P T x$ phase diagram for $\mathrm{NH}_{3}$ and $\left[\mathrm{C}_{2} \mathrm{C}_{1} \mathrm{im}\right]\left[\mathrm{NTf}_{2}\right]$ at $283.15,298.15,318.15$, and 338.15 K. Symbols represent experimental data, and solid lines represents PR-EoS model.

computed using an arbitrary high $T_{\mathrm{c}}$ (i.e., $1245 \mathrm{~K}$ ). For both $\left[\mathrm{C}_{4} \mathrm{C}_{1} \mathrm{im}\right]\left[\mathrm{BF}_{4}\right]+\mathrm{NH}_{3}$ and $\left[\mathrm{C}_{4} \mathrm{C}_{1} \mathrm{im}\right]\left[\mathrm{PF}_{6}\right]+\mathrm{NH}_{3}$ systems, the impact of $T_{c}$ on the fit (AARD\%) was $\pm \sim 1 \%$ and $\pm 2 \%$, 
respectively; therefore, the results indicate that the $T_{c}$ calculated in Table 3 can be used to correlate $\mathrm{NH}_{3}+\mathrm{IL}$ systems using the PR-EoS model.

Pure component parameters:

$$
\begin{aligned}
& a_{i}=\frac{0.45724 R^{2} T_{c_{i}}^{2}}{P_{c_{i}}} \alpha_{i}(T) \\
& b_{i}=\frac{0.07780 R T_{c_{i}}}{P_{c_{i}}}
\end{aligned}
$$

Alpha Function:

$$
\begin{aligned}
& \alpha_{i}(T)=\left(1+m_{i}\left(1-\sqrt{T_{r}}\right)\right)^{2} \\
& m_{i}=0.37464+1.54226 \omega_{i}-0.26992 \omega_{i}^{2} \\
& T_{r_{i}}=\frac{T_{i}}{T_{c_{i}}}
\end{aligned}
$$

Mixing rule:

$$
\begin{aligned}
a_{m}= & \sum_{i} \sum_{j} x_{i} x_{j}\left(1-k_{i j}\right)\left(a_{i} a_{j}\right)^{1 / 2} \\
& +\sum_{i} x_{i}\left(\sum_{j} x_{j}\left(\left(a_{i} a_{j}\right)^{1 / 2} l_{i j}\right)^{1 / 3}\right)^{3} \\
k_{i j}= & k_{i j}^{(1)}+k_{i j}^{(2)} T+\frac{k_{i j}^{(3)}}{T} \text { and } l_{i j}=l_{i j}^{(1)}+l_{i j}^{(2)} T+\frac{l_{i j}^{(3)}}{T} \\
b_{\mathrm{m}}= & \sum_{i} x_{i} b_{i}
\end{aligned}
$$

3.2.3. Activity Coefficient Model. At low to medium pressures, EoS models can be used to estimate the vapor phase fugacity as nonidealities in the vapor phase are usually small. On the other hand, nonidealities in the liquid phase can be large; therefore, the EoS with van der Waals one fluid mixing rules may not reasonably predict the liquid phase fugacities. ${ }^{38}$ Alternatively, EoS models with excess free energy based mixing rules can be used to estimate the liquid phase fugacities at all temperatures and pressures. ${ }^{38}$ However, modeling the experimental data with EoS models is usually more tedious while activity coefficient models are simple to estimate the liquid phase fugacities at low pressures. When two different models are used (an activity coefficient model for the liquid phase and an EoS model for the vapor phase), the critical point of the mixture might be incorrectly predicted because the properties of the two phases might not be identical. ${ }^{38}$ However, considering the critical point of the mixture is considerably high, using two different models can accurately estimate the VLE of $\mathrm{NH}_{3}$ and IL mixtures. Therefore, in this study, the vapor liquid equilibria of $\mathrm{NH}_{3}+$ IL mixtures were also modeled using the Non-Random Two Liquid (NRTL) solution model for the liquid phase and the Second Virial Coefficient correction for the vapor phase.

For low and medium pressure, VLE for an $N$-component system can be described: ${ }^{24}$

$$
y_{i} P \phi_{i}=x_{i} \gamma_{i} P_{i}^{\text {vap }}
$$

where $y_{i}$ is the vapor phase mole fraction for $i$ th species, $x_{i}$ is the liquid phase mole fraction for $i$ th species, $P$ is pressure, $P_{i}^{\text {vap }}$ is the saturated vapor pressure for ith species, $\phi i$ is a Poynting pressure correction factor for $i$ th species of a gas, and $\gamma_{i}$ is the activity coefficient for $i$ th species (function of composition at $T)$. For a binary system of $\mathrm{NH}_{3}+\mathrm{IL}$ mixtures, it is reasonable to assume that the solubility of IL in $\mathrm{NH}_{3}$ is negligible $\left(\mathrm{P}_{\mathrm{IL}}{ }^{\text {vap }}\right.$ $\approx 0$ ) so $y_{\mathrm{NH}_{3}}=1$ ( or $y_{\mathrm{IL}}=0$ ). The activity coefficient of $\mathrm{NH}_{3}$ (1) is given by

$$
\gamma_{1}=\frac{P \phi_{1}}{x_{1} P_{1}^{\text {vap }}}
$$

The Poynting pressure correction factor $\left(\phi_{1}\right)$ for $\mathrm{NH}_{3}$ in the present case is

$$
\phi_{1}=\exp \left[\frac{\left(B_{1}-\tilde{V}_{1}\right)\left(P-P_{1}^{\mathrm{vap}}\right)}{R T}\right]
$$

where $B_{1}(T)$ is the second virial coefficient of $\mathrm{NH}_{3}$ at system $T, \tilde{V}_{1}$ is the saturated molar liquid volume at system $T$, and $R$ is the universal gas constant. The $B_{1}(T)$ is obtained using the NIST REFPROP computer code v.9.1. ${ }^{25} \tilde{V}_{1}$ can be calculated as described in the Supporting Information, and $P_{1}^{\text {vap }}$ can be obtained using the Extended Antione vapor pressure model:

$$
\ln P_{i}^{\text {vap }}=A+\frac{B}{T+C}+D T+E \ln T+F T^{G}
$$

where $T(K), P_{i}^{\text {vap }}(k P a)$, and coefficients are given as $A=$ 83.58, $B=-4669.70, C=0, D=0, E=-11.61, F=0.02$, and $G=1 .{ }^{36}$ The activity coefficients were calculated using the NRTL equations:

$$
\begin{aligned}
& \ln \gamma_{1}=x_{2}^{2}\left[\tau_{21}\left(\frac{G_{21}}{x_{1}+x_{2} G_{21}}\right)^{2}+\frac{\tau_{12} G_{12}}{\left(x_{2}+x_{1} G_{12}\right)^{2}}\right] \\
& \ln \gamma_{2}=x_{1}^{2}\left[\tau_{12}\left(\frac{G_{12}}{x_{2}+x_{1} G_{12}}\right)^{2}+\frac{\tau_{21} G_{21}}{\left(x_{1}+x_{2} G_{21}\right)^{2}}\right]
\end{aligned}
$$

where $G_{12}$ and $G_{21}$ are defined by the interaction parameters $\left(\tau_{12}, \tau_{12}, \alpha\right)$ :

$$
G_{12} \equiv \exp \left(-\alpha \tau_{12}\right) \text { and } G_{21} \equiv \exp \left(-\alpha \tau_{21}\right)
$$

where the nonrandomness factor $(\alpha)$ is assumed to be a constant of 0.2 . In this study, binary interaction parameters were obtained using only temperature-dependent terms:

$$
\tau_{12}=\tau_{12}^{(0)}+\tau_{12}^{(1)} / T(K) \text { and } \tau_{21}=\tau_{21}^{(0)}+\tau_{21}^{(1)} / T(K)
$$

The regressed binary interaction parameters are summarized in Table 5.

The experimental VLE results and NRTL models are shown in Figures 5, 6, and 7. The models accurately predict the VLE for each of the three systems with an average overall difference of less than 5\% AARD. The activity coefficient model for the

Table 5. Binary Interaction Parameters for the NRTL Activity Coefficient Model

\begin{tabular}{cccrr}
\multicolumn{1}{c}{ System $(1) /(2)$} & $\tau_{12}{ }^{(0)}$ & $\tau_{12}{ }^{(1)}(\mathrm{K})$ & \multicolumn{1}{c}{$\tau_{21}{ }^{(0)}$} & $\tau_{21}{ }^{(1)}(\mathrm{K})$ \\
$\mathrm{NH}_{3}+\left[\mathrm{C}_{2} \mathrm{C}_{1} \mathrm{im}\right]\left[\mathrm{NTf}_{2}\right]$ & -3.306 & 1669.7 & -0.1201 & -730.79 \\
$\mathrm{NH}_{3}+\left[\mathrm{C}_{4} \mathrm{C}_{1} \mathrm{im}\right]\left[\mathrm{PF}_{6}\right]$ & -2.439 & 1350.8 & 0.3428 & -815.96 \\
$\mathrm{NH}_{3}+\left[\mathrm{C}_{4} \mathrm{C}_{1} \mathrm{im}\right]\left[\mathrm{BF}_{4}\right]$ & -4.871 & 2634.5 & -0.1423 & -891.45
\end{tabular}




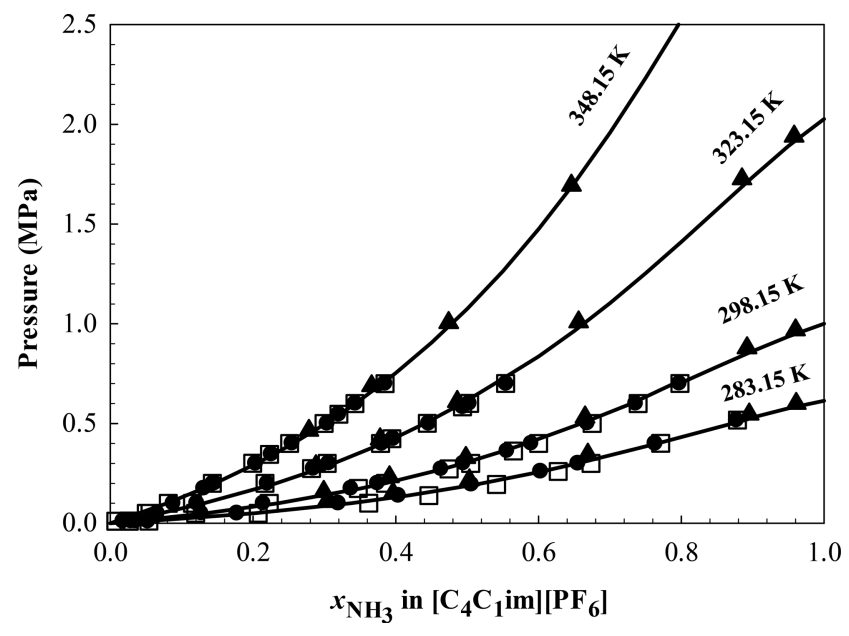

Figure 5. $P T x$ phase diagram for $\mathrm{NH}_{3}$ and $\left[\mathrm{C}_{4} \mathrm{C}_{1} \mathrm{im}\right]\left[\mathrm{PF}_{6}\right]$ at 283.15, 298.15, 318.15, and 338.15 K. Symbols: (๑) absorption data; ( $\square$ ) desorption data; $(\boldsymbol{\Delta})$ Tomida et al. $^{8}$ Solid lines: NRTL model in this study.

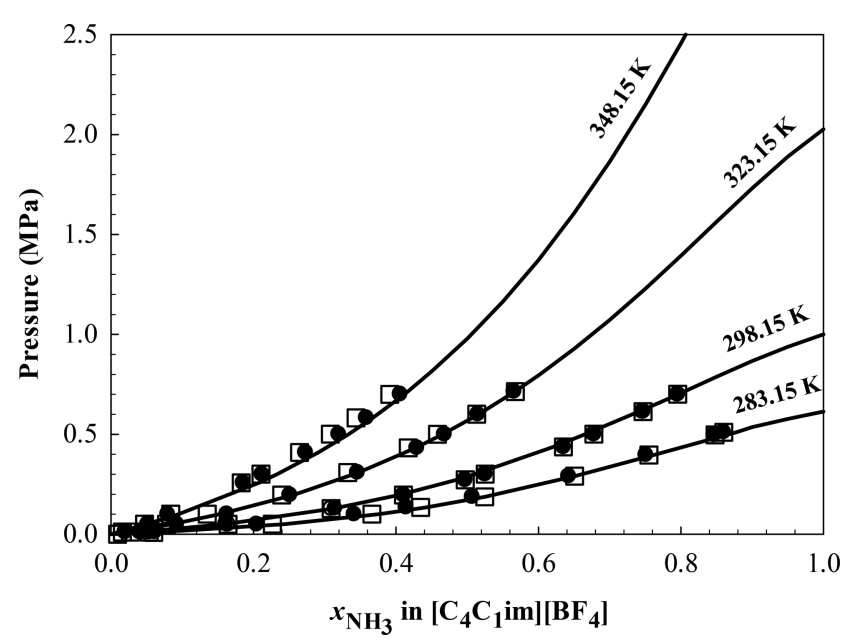

Figure 6. $P T x$ phase diagram for $\mathrm{NH}_{3}$ and $\left[\mathrm{C}_{4} \mathrm{C}_{1} \mathrm{im}\right]\left[\mathrm{BF}_{4}\right]$ at 283.15 , $298.15,318.15$, and $338.15 \mathrm{~K}$. Symbols: $(\bullet)$ absorption data; $(\square)$ desorption data. Solid lines represent NRTL model.

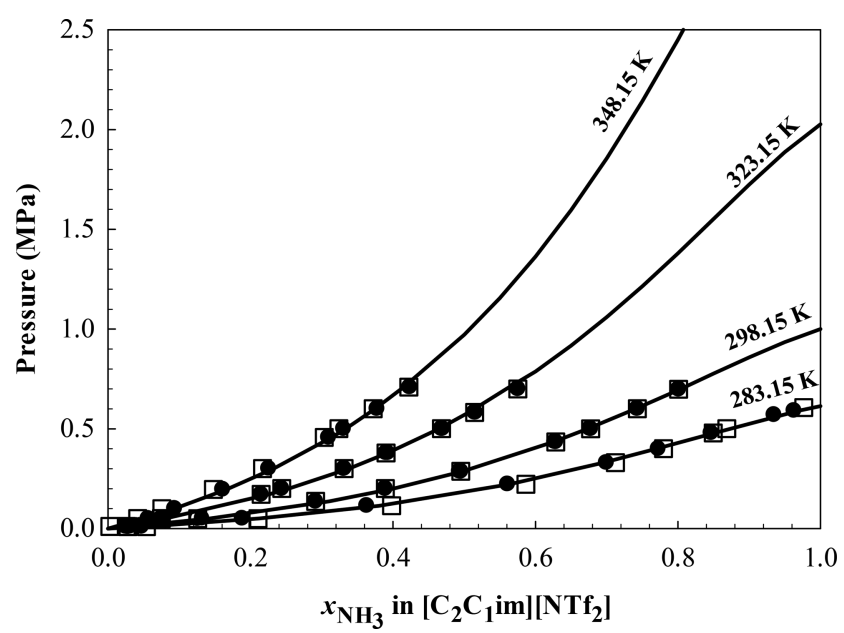

Figure 7. $P$ Tx phase diagram for $\mathrm{NH}_{3}$ and $\left[\mathrm{C}_{2} \mathrm{C}_{1} \mathrm{im}\right]\left[\mathrm{NTf}_{2}\right]$ at $283.15,298.15$, 318.15, and 338.15 K. Symbols: $(\bullet)$ absorption data;

$(\square)$ desorption data. Solids lines represent NRTL model.
$\mathrm{NH}_{3}$ and $\left[\mathrm{C}_{4} \mathrm{C}_{1} \mathrm{im}\right]\left[\mathrm{PF}_{6}\right]$ system is also compared with results reported by Tomida et al. ${ }^{8}$ The activity coefficient model accurately estimated the $\mathrm{NH}_{3}$ composition at high pressures using only low pressure (up to $0.7 \mathrm{MPa}$ ) VLE measurements. The average absolute relative deviation between this study and Tomida et al. ${ }^{8}$ was $5.1 \%, 3.5 \%, 2.5 \%$, and $2.8 \%$ AARD at $283.15,298.15,323.15$, and $348.15 \mathrm{~K}$, respectively. The excellent agreement between the model obtained in this study and the high pressure experimental data obtained by Tomida et $\mathrm{al}^{8}{ }^{8}$ indicates the low pressure solubility measurements were highly accurate. The models also do not predict any liquidliquid phase separation at high $\mathrm{NH}_{3}$ concentration.

Chemical interaction between $\mathrm{NH}_{3}$ and imidazolium-based ILs was also considered by measuring the desorption of $\left[\mathrm{C}_{4} \mathrm{C}_{1} \mathrm{im}\right]\left[\mathrm{PF}_{6}\right], \quad\left[\mathrm{C}_{4} \mathrm{C}_{1} \mathrm{im}\right]\left[\mathrm{BF}_{4}\right]$, and $\left[\mathrm{C}_{2} \mathrm{C}_{1} \mathrm{im}\right]\left[\mathrm{NTf}_{2}\right]$ at temperatures of $283.15,298.15,323.15$, and $348.15 \mathrm{~K}$ and at pressures ranging from 0.010 to $0.7 \mathrm{MPa}$. The desorption data are shown in Figures 5, 6, and 7. At some conditions, particularly at low $T$ and low $P$, the difference between absorption and desorption solubility was as high as $\sim 3 \mathrm{~mol} \%$. This difference between the equilibrium concentrations for the given isotherms during absorption and desorption suggests the interaction between $\mathrm{NH}_{3}$ and imidazolium-based ILs may be both chemical and physical. The interaction of $\mathrm{NH}_{3}$ and ILs requires more in-depth spectroscopic analysis which is currently under investigation.

3.2.4. Comparison of $\mathrm{NH}_{3}+\left[\mathrm{C}_{4} \mathrm{C}_{1}\right.$ im] $\left[\mathrm{PF}_{6}\right], \mathrm{NH}_{3}+$ $\left[C_{4} C_{1}\right.$ im] $\left[B F_{4}\right]$, and $\mathrm{NH}_{3}+\left[\mathrm{C}_{2} \mathrm{C}_{7}\right.$ im] $\left[N \mathrm{Nf}_{2}\right]$ Systems. The solubility of $\mathrm{NH}_{3}$ in $\left[\mathrm{C}_{4} \mathrm{C}_{1} \mathrm{im}\right]\left[\mathrm{PF}_{6}\right],\left[\mathrm{C}_{4} \mathrm{C}_{1} \mathrm{im}\right]\left[\mathrm{BF}_{4}\right]$, and $\left[\mathrm{C}_{2} \mathrm{C}_{1} \mathrm{im}\right]\left[\mathrm{NTf}_{2}\right]$ were also compared at $298.15 \mathrm{~K}$. As can be seen in Figure 8, all three ILs have very similar $\mathrm{NH}_{3}$ sorption

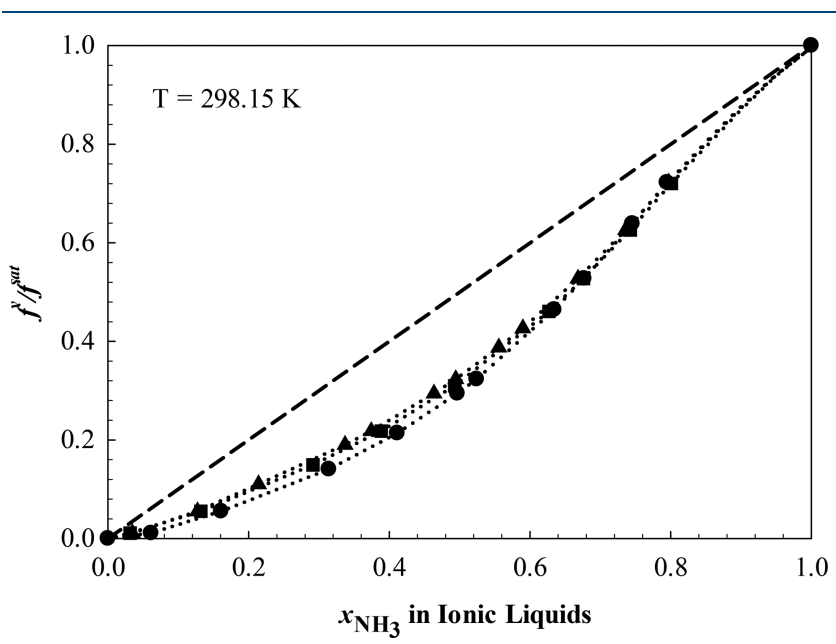

Figure 8. Normalized fugacity of $\mathrm{NH}_{3}$ in $\left[\mathrm{C}_{4} \mathrm{C}_{1} \mathrm{im}\right]\left[\mathrm{PF}_{6}\right],\left[\mathrm{C}_{4} \mathrm{C}_{1} \mathrm{im}\right]$ $\left[\mathrm{BF}_{4}\right]$, and $\left[\mathrm{C}_{2} \mathrm{C}_{1} \mathrm{im}\right]\left[\mathrm{NTf}_{2}\right]$ at $298.15 \mathrm{~K}$. Symbols: $(\boldsymbol{\Delta})\left[\mathrm{C}_{4} \mathrm{C}_{1} \mathrm{im}\right]-$ $\left[\mathrm{PF}_{6}\right] ;(\boldsymbol{\square})\left[\mathrm{C}_{2} \mathrm{C}_{1} \mathrm{im}\right]\left[\mathrm{NTf}_{2}\right] ;(\boldsymbol{\bullet})\left[\mathrm{C}_{4} \mathrm{C}_{1} \mathrm{im}\right]\left[\mathrm{BF}_{4}\right]$. Lines: dashed line, Raoult's law; dotted line, an activity coefficient model calculated from experimental data.

capacities even though there is a slight difference between the solubilities up to $\sim 0.72$ mole fraction $\mathrm{NH}_{3}$ following the order: $\left[\mathrm{C}_{4} \mathrm{C}_{1} \mathrm{im}\right]\left[\mathrm{PF}_{6}\right]<\left[\mathrm{C}_{2} \mathrm{C}_{1} \mathrm{im}\right]\left[\mathrm{NTf}_{2}\right]<\left[\mathrm{C}_{4} \mathrm{C}_{1} \mathrm{im}\right]\left[\mathrm{BF}_{4}\right]$. Above 0.72 mole fraction $\mathrm{NH}_{3}$, all three ILs demonstrated similar solubility behavior at $298.15 \mathrm{~K}$. The $\left[\mathrm{C}_{4} \mathrm{C}_{1} \mathrm{im}\right]\left[\mathrm{PF}_{6}\right]$ and $\left[\mathrm{C}_{4} \mathrm{C}_{1} \mathrm{im}\right]\left[\mathrm{BF}_{4}\right]$ ILs share the same cation and show a slight difference in solubility; therefore, the anion may have only a minor impact on the $\mathrm{NH}_{3}$ solubility. If we assume the anion has a minor effect on solubility, then the shorter alkyl chain 
Table 6. Average Effective Diffusion Coefficients for $\mathrm{NH}_{3}$ in $\left[\mathrm{C}_{4} \mathrm{C}_{1} \mathrm{im}\right]\left[\mathrm{PF}_{6}\right],\left[\mathrm{C}_{4} \mathrm{C}_{1} \mathrm{im}\right]\left[\mathrm{BF}_{4}\right]$, and $\left[\mathrm{C}_{2} \mathrm{C}_{1} \mathrm{im}\right]\left[\mathrm{NTf}_{2}\right]$ Systems

\begin{tabular}{ccccc} 
& \multicolumn{4}{c}{ Diffusivity $\left(\times 10^{-10} \mathrm{~m}^{2} \cdot \mathrm{s}^{-1}\right)^{a}$} \\
\cline { 2 - 5 } Ionic Liquid & $T=283.15 \mathrm{~K}$ & $T=298.15 \mathrm{~K}$ & $T=323.15 \mathrm{~K}$ & $T=348.15 \mathrm{~K}$ \\
{$\left[\mathrm{C}_{4} \mathrm{C}_{1} \mathrm{im}\right]\left[\mathrm{PF}_{6}\right]$} & $1.9 \pm 0.13$ & $3.1 \pm 0.07$ & $4.0 \pm 0.04$ & $7.1 \pm 0.22$ \\
{$\left[\mathrm{C}_{4} \mathrm{C}_{1} \mathrm{im}\right]\left[\mathrm{BF}_{4}\right]$} & $1.8 \pm 0.09$ & $3.3 \pm 0.13$ & $4.8 \pm 0.05$ & $6.0 \pm 0.26$ \\
{$\left[\mathrm{C}_{2} \mathrm{C}_{1} \mathrm{im}\right]\left[\mathrm{NTf}_{2}\right]$} & $2.8 \pm 0.25$ & $5.2 \pm 0.16$ & $8.5 \pm 0.65$ & $18.3 \pm 2.1$
\end{tabular}

${ }^{a_{T}}$ The uncertainties are due to the random errors as a result of mass measurement in the balance and systematic error as a result of change in $L$.

length may lead to an increase in $\mathrm{NH}_{3}$ solubility $\left(\left[\mathrm{C}_{4} \mathrm{C}_{1} \mathrm{im}\right]\right.$ $\left.\left[\mathrm{PF}_{6}\right]<\left[\mathrm{C}_{2} \mathrm{C}_{1} \mathrm{im}\right]\left[\mathrm{NTf}_{2}\right]\right)$. Figure 8 also shows the large negative deviation from ideal solubility behavior (Raoult's law) indicating a strong $\mathrm{NH}_{3}$-IL interaction.

3.3. Absorption Kinetics and Diffusion Coefficients. In addition to the thermodynamic analysis of $\mathrm{NH}_{3}$ and IL mixtures, the time-dependent behavior of $\mathrm{NH}_{3}$ dissolution in ILs was analyzed with a simplified Fickian diffusion model. Detailed procedures of the diffusivity analysis are discussed by Shiflett and Yokozeki. ${ }^{39}$ In the simplified mathematical model, the following assumptions are made: ${ }^{24}(i)$ gas dissolves through a one-dimensional (vertical) diffusion process, and there is no convective flow in the liquid; (ii) the interaction between gas and IL is physical; (iii) a thin boundary layer between the IL and gas phase exists, and the layer reaches a saturation concentration $\left(C_{s}\right)$ at any given temperature and pressure (Boundary Condition 1); (iv) temperature and pressure are constant (experimental design); (v) the $\mathrm{NH}_{3}-$ IL solution is dilute, and the thermophysical properties are constant at a given $T$ and $P$ condition; and $(v i)$ gas does not penetrate through the Pyrex cup (Boundary Condition 2). These assumptions lead to the dissolution of gas in the IL for one-dimensional (1D) mass diffusion due to the local concentration difference:

$$
D \frac{\partial^{2} C}{\partial z^{2}}=\frac{\partial C}{\partial t}
$$

where $C$ is the concentration of $\mathrm{NH}_{3}$ in IL, $t$ is the time, $z$ is the vertical location, and $L$ is the depth of IL in the sample container. In this study, the depth $(L)$ is estimated from the solution mass, the dimension of the sample cup, and the weight fraction averaged density of the solution at initial and final composition for a given $T$ and $P$. Equation 21 can be analytically solved using a separation of variables technique and applying the proper initial and boundary conditions (eqs $22-24)$, to obtain the concentration profile in the $z$ direction (eq 25).

$$
\begin{array}{lccl}
\text { Initial Condition: } & \mathrm{t}=0 & 0<\mathrm{z}<L & \mathrm{C}=\mathrm{C}_{\mathrm{o}} \\
\text { Boundary Condition 1: } & \mathrm{t}>0 & \mathrm{z}=0 & \mathrm{C}=\mathrm{C}_{\mathrm{s}} \\
\text { Boundary Condition 2: } & \mathrm{t}>0 & \mathrm{z}=L & \frac{\partial \mathrm{C}}{\partial \mathrm{z}}=0 \\
C=C_{\mathrm{s}}\left[1-2\left(1-\frac{C_{0}}{C_{\mathrm{s}}}\right) \sum_{n=0}^{\infty} \frac{\exp \left(-\lambda_{n}^{2} D t\right) \sin \lambda_{n} \mathrm{z}}{L \lambda_{n}}\right]
\end{array}
$$

The concentration obtained in the microbalance is the average concentration at a given time, not the concentration profile in $z$; therefore, the space averaged concentration at a given time can be obtained using the following equations:

$$
\langle C\rangle=\int_{0}^{L} \frac{C}{L} \mathrm{~d} z
$$

$$
\langle C\rangle=C_{s}\left[1-2\left(1-\frac{C_{0}}{C_{s}}\right) \sum_{n=0}^{\infty} \frac{\exp \left(-\lambda_{n}^{2} D t\right)}{L^{2} \lambda_{n}^{2}}\right]
$$

Although eq 27 has an infinite summation term, only the first few terms are required for most analysis and the summation term was terminated when the numerical contribution is infinitely small. At any given $T$ and $P$, experimentally measured concentration as a function of time can be fit using eq 27 to obtain $D$ and $C_{s}$. The effective $D$ value at each $P$ for a given isotherm was obtained by averaging the calculated $D$ obtained using a constant height of the solution at initial $\left(C_{0}\right)$ and final $\left(C_{s}\right.$, saturation $)$ compositions. The analysis of eq 27 was performed using nonlinear regression in MATLAB. Tables S2-S4 in the Supporting Information summarizes the results for $C_{s}$ and $D$ for $\mathrm{NH}_{3}+\left[\mathrm{C}_{4} \mathrm{C}_{1} \mathrm{im}\right]\left[\mathrm{PF}_{6}\right]$, $\mathrm{NH}_{3}+\left[\mathrm{C}_{4} \mathrm{C}_{1} \mathrm{im}\right]\left[\mathrm{BF}_{4}\right]$, and $\mathrm{NH}_{3}+\left[\mathrm{C}_{2} \mathrm{C}_{1} \mathrm{im}\right]\left[\mathrm{NTf}_{2}\right]$. The effective $D$ for each system as a function of temperature are summarized in Table 6 . As expected, the diffusivity of $\mathrm{NH}_{3}$ in $\left[\mathrm{C}_{4} \mathrm{C}_{1} \mathrm{im}\right]\left[\mathrm{PF}_{6}\right], \quad\left[\mathrm{C}_{4} \mathrm{C}_{1} \mathrm{im}\right]\left[\mathrm{BF}_{4}\right]$, and $\left[\mathrm{C}_{2} \mathrm{C}_{1} \mathrm{im}\right]\left[\mathrm{NTf}_{2}\right]$ increases with an increase in temperature as the viscosity of the solution decreases. However, at constant $T$, the pressure dependence of $D$ is rather weak compared to temperature. A key finding in this part of the study is that the diffusivity of $\mathrm{NH}_{3}$ in $\left[\mathrm{C}_{4} \mathrm{C}_{1} \mathrm{im}\right]\left[\mathrm{PF}_{6}\right],\left[\mathrm{C}_{4} \mathrm{C}_{1} \mathrm{im}\right]\left[\mathrm{BF}_{4}\right]$, and $\left[\mathrm{C}_{2} \mathrm{C}_{1} \mathrm{im}\right]\left[\mathrm{NTf}_{2}\right]$ is about 3 to 5 times lower than the diffusion of $\mathrm{NH}_{3}$ in water. For example, the diffusivity of $\mathrm{NH}_{3}$ in water at $298.15 \mathrm{~K}$ is 16 $\times 10^{-10} \mathrm{~m}^{2} \cdot \mathrm{s}^{40}$ whereas the diffusivity of $\mathrm{NH}_{3}$ in $\left[\mathrm{C}_{4} \mathrm{C}_{1} \mathrm{im}\right]$ $\left[\mathrm{PF}_{6}\right],\left[\mathrm{C}_{4} \mathrm{C}_{1} \mathrm{im}\right]\left[\mathrm{BF}_{4}\right]$, and $\left[\mathrm{C}_{2} \mathrm{C}_{1} \mathrm{im}\right]\left[\mathrm{NTf}_{2}\right]$ at $298.15 \mathrm{~K}$ is 3.1 $\times 10^{-10}, 3.3 \times 10^{-10}$, and $5.2 \times 10^{-10}$, respectively.

One way to test the model validity is to check the $\mathrm{NH}_{3}$ solubility $\left(C_{s}\right)$ determined from the present analysis. If the model is physically meaningful, the $C_{s}$ values should be consistent with the experimental solubility values. In fact, the difference between the experimental solubility and model $C_{s}$ values was less than $\sim 1 \mathrm{~mol} \%$ for all systems which indicates the model reasonably predicts the $C_{s}$ and $D$ values. A few comments also should be made regarding the $D$ values. Contrary to the main assumptions of the model, the $\mathrm{NH}_{3}+\mathrm{IL}$ mixtures cannot be considered as dilute solution, and consequently the diffusion coefficients can depend on the concentration. In reality, the thermophysical properties of the mixture change upon gas dissolution, and $L$ varies with the amount of gas dissolved in the IL. Therefore, when we apply the present model, the analyzed diffusion coefficients must be regarded as "effective" or "apparent" diffusion coefficients.

3.3.1. Stokes-Einstein Model. When a solute sphere (with radius $r_{A}$ ) moves through a continuum fluid, the StokesEinstein equation correlates the diffusion coefficient $\left(D_{A B}\right)$ and the viscosity of solvent $\left(\mu_{B}\right)$ assuming the diffusing particle is perfectly spherical where $k$ is the Boltzmann constant and $T$ is the temperature: 
Table 7. Coefficients for Equation $33^{a}$

\begin{tabular}{llll}
\multicolumn{1}{c}{ Compound i } & \multicolumn{1}{c}{$A_{i}$} & $B_{i}(\mathrm{~K})$ & $C_{i}\left(\mathrm{~K}^{-1}\right)$ \\
& -5.130771 & 922.2 & 0 \\
$\mathrm{NH}_{3}{ }^{b}$ & -182.774 & 24992.4 & $4.84019 \times 10^{-1}$ \\
{$\left[\mathrm{C}_{4} \mathrm{C}_{1} \mathrm{im}\right]\left[\mathrm{PF}_{6}\right]^{c}$} & -149.99 & 20757.8 & $3.91576 \times 10^{-1}$ \\
{$\left[\mathrm{C}_{4} \mathrm{C}_{1} \mathrm{im}\right]\left[\mathrm{BF}_{4}\right]^{c}$} & -60.707 & 9364.9 & $1.49780 \times 10^{-1}$ \\
{$\left[\mathrm{C}_{2} \mathrm{C}_{1} \mathrm{im}\right]\left[\mathrm{NTf}_{2}\right]^{d}$} & $-4.44779 \times 10^{-4}$
\end{tabular}

${ }^{a}$ Viscosity in $\mathrm{mPa} \cdot \mathrm{s}$ ( or $\mathrm{cP}$ ), and $\mathrm{T}$ in $\mathrm{K} .{ }^{b}$ Parameters obtained using linear fitting of viscosity data from ref $25 .{ }^{c}$ Parameters are taken from ref 41 . ${ }^{d}$ Parameters obtained using linear fitting of viscosity data from ref 42.

Table 8. Determined Parameters for Equations 30 and $32^{a}$

$\begin{array}{ccccc}\text { System } & a\left(\mathrm{ln} \mathrm{m}^{2} \cdot \mathrm{s}^{-1} \cdot \mathrm{K}^{-1}\right) & b\left(\mathrm{ln} \mathrm{m}^{2} \cdot \mathrm{s}^{-1} \cdot \mathrm{K}^{-1}\right) & c & \text { Radius }(\mathrm{nm}) \\ \mathrm{NH}_{3}+\left[\mathrm{C}_{4} \mathrm{C}_{1} \mathrm{im}\right]\left[\mathrm{PF}_{6}\right] & -25.880 \pm 0.186 & 0.466 \pm 0.046 & 0.502 \pm 0.029 & 0.127 \pm 0.024 \\ \mathrm{NH}_{3}+\left[\mathrm{C}_{4} \mathrm{C}_{1} \mathrm{im}\right]\left[\mathrm{BF}_{4}\right] & -26.142 \pm 0.253 & 0.504 \pm 0.095 & 0.438 \pm 0.034 & 0.165 \pm 0.042 \\ \mathrm{NH}_{3}+\left[\mathrm{C}_{2} \mathrm{C}_{1} \mathrm{im}\right]\left[\mathrm{NTf}_{2}\right] & -25.742 \pm 0.240 & 0.458 \pm 0.093 & 0.899 \pm 0.021 & 0.111 \pm 0.027\end{array}$

${ }^{a}$ Errors are the standard uncertainty obtained in regression analysis.

$$
D_{A B}=\frac{k T}{6 \pi r_{A} \mu_{B}}
$$

An empirical correlation for diffusivity of gases was developed using a semitheoretical Stokes-Einstein equation: ${ }^{24}$

$$
D=\frac{k T}{6 \pi r \mu_{o}\left(\mu / \mu_{o}\right)^{b}}
$$

The linearized form of eq 29 can be written as

$$
\ln (D / T)=a-b \ln \left(\mu / \mu_{o}\right)
$$

where $D$ is diffusivity $\left(\mathrm{m}^{2} \mathrm{~s}^{-1}\right), k$ is the Boltzmann constant, $T$ is temperature $(\mathrm{K})$, and $\mu_{o}$ is a unit viscosity $(1 \mathrm{mPa} \cdot \mathrm{s})$ that is used as a normalization factor to have proper dimension in the equation. $a=\ln \left(k / 6 \pi r \mu_{o}\right)$ and $b$ are the adjustable parameters.

The mixture viscosity for an $N$-component solution can be estimated using the following model: ${ }^{24}$

$$
\ln \left(\mu / \mu_{o}\right)=\sum_{i=1}^{N} \xi_{i} \ln \left(\mu_{i} / \mu_{o}\right)
$$

where

$$
\xi_{i}=M_{i}^{c} x_{i} / \sum_{i=1}^{N} M_{i}^{c} x_{i}
$$

and $M_{i}$ is the molecular weight of the $i$ th species. The model has three empirical adjustable parameters $(a, b$, and $c)$ to correlate the observed diffusivity data. The dynamic viscosity of a pure compound $i$ is modeled as

$$
\ln \left(\mu_{i}\right)=A_{i}+\frac{B_{i}}{T}+C_{i} T+D_{i} T^{2}
$$

The coefficients for $\mathrm{NH}_{3},\left[\mathrm{C}_{4} \mathrm{C}_{1} \mathrm{im}\right]\left[\mathrm{PF}_{6}\right],\left[\mathrm{C}_{4} \mathrm{C}_{1} \mathrm{im}\right]\left[\mathrm{BF}_{4}\right]$, and $\left[\mathrm{C}_{2} \mathrm{C}_{1}\right.$ im $]\left[\mathrm{NTf}_{2}\right]$ in eq 33 are provided in Table 7 .

The diffusivity of $\mathrm{NH}_{3}$ in the ILs was correlated using this generalized form of the Stokes-Einstein equation. The adjustable parameters ( $a, b$, and $c$ ) were obtained using nonlinear regression which is summarized in Table 8 . The empirical parameter $a$ consists of the physical parameter which is the radius of the diffusing solute. Therefore, the radius of $\mathrm{NH}_{3}$ is calculated using the interaction parameter $a$. If the model is physically meaningful, the radius of $\mathrm{NH}_{3}$ obtained using this model should be close to the molecular radius of $\mathrm{NH}_{3}$ (or at least the same order of magnitude). Indeed, $r$ in
$\left[\mathrm{C}_{4} \mathrm{C}_{1} \mathrm{im}\right]\left[\mathrm{PF}_{6}\right]=0.127 \mathrm{~nm}, r$ in $\left[\mathrm{C}_{4} \mathrm{C}_{1} \mathrm{im}\right]\left[\mathrm{BF}_{4}\right]=0.165$, and $r$ in $\left[\mathrm{C}_{2} \mathrm{C}_{1} \mathrm{im}\right]\left[\mathrm{NTf}_{2}\right]=0.111 \mathrm{~nm}$ are remarkably close to the molecular radius of $\mathrm{NH}_{3}(0.182 \mathrm{~nm}){ }^{43}$ The model calculations for $\mathrm{NH}_{3}$ in $\left[\mathrm{C}_{4} \mathrm{C}_{1} \mathrm{im}\right]\left[\mathrm{PF}_{6}\right], \mathrm{NH}_{3}$ in $\left[\mathrm{C}_{4} \mathrm{C}_{1} \mathrm{im}\right]\left[\mathrm{BF}_{4}\right]$, and $\mathrm{NH}_{3}$ in $\left[\mathrm{C}_{2} \mathrm{C}_{1} \mathrm{im}\right]\left[\mathrm{NTf}_{2}\right]$ are compared with experimental diffusivity data in Figures 9, 10, and 11. The model calculations are in

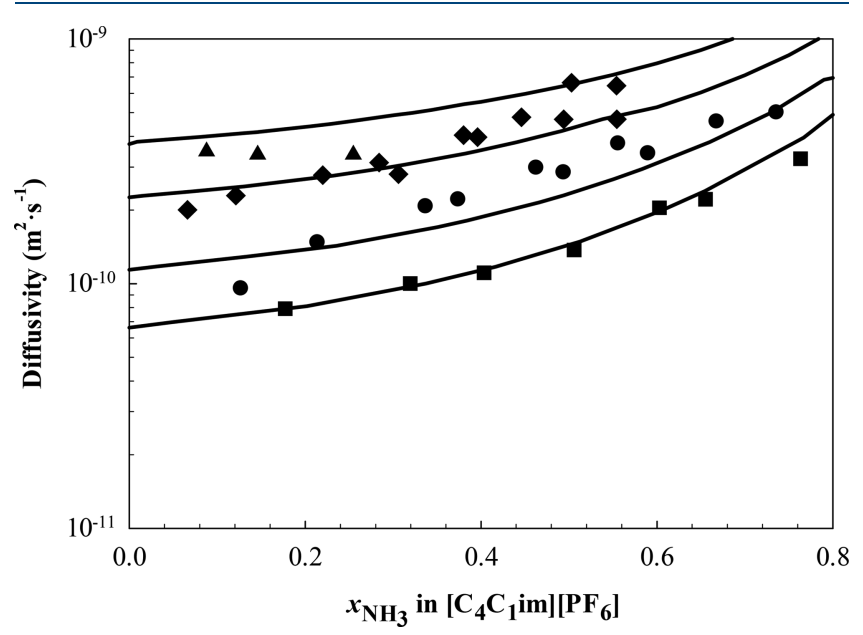

Figure 9. Diffusivity of $\mathrm{NH}_{3}$ in $\left[\mathrm{C}_{4} \mathrm{C}_{1} \mathrm{im}\right]\left[\mathrm{PF}_{6}\right]$. Lines represent model calculations, and symbols represent experimental data:

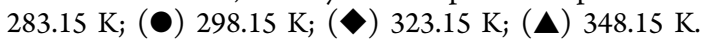

good agreement with a maximum error of less than $5 \%$. The results show that the modified form of the Stokes-Einstein equation $^{24}$ along with the viscosity model can be used to correlate the diffusion of $\mathrm{NH}_{3}$ in imidazolium-based ILs. However, the Stokes-Einstein analysis is sensitive to the solution viscosity; therefore, experimental measurement of thermophysical properties (i.e., viscosity) of $\mathrm{NH}_{3}+\mathrm{IL}$ mixtures which is not present in the literature is currently under investigation.

\section{CONCLUSION}

The first vapor liquid equilibrium (VLE) measurements for the binary systems of $\mathrm{NH}_{3}$ and three imidazolium-based ILs have been successfully measured using a gravimetric microbalance. The vapor liquid equilibrium (VLE) for the binary systems of $\mathrm{NH}_{3}$ and imidazolium-based ILs $\left[\mathrm{C}_{4} \mathrm{C}_{1} \mathrm{im}\right]\left[\mathrm{PF}_{6}\right],\left[\mathrm{C}_{4} \mathrm{C}_{1} \mathrm{im}\right]$ $\left[\mathrm{BF}_{4}\right]$, and $\left[\mathrm{C}_{2} \mathrm{C}_{1} \mathrm{im}\right]\left[\mathrm{NTf}_{2}\right]$ were measured at 283.15, 298.15, 323.15 , and $348.15 \mathrm{~K}$ with pressures up to $7 \mathrm{MPa}$ using a 


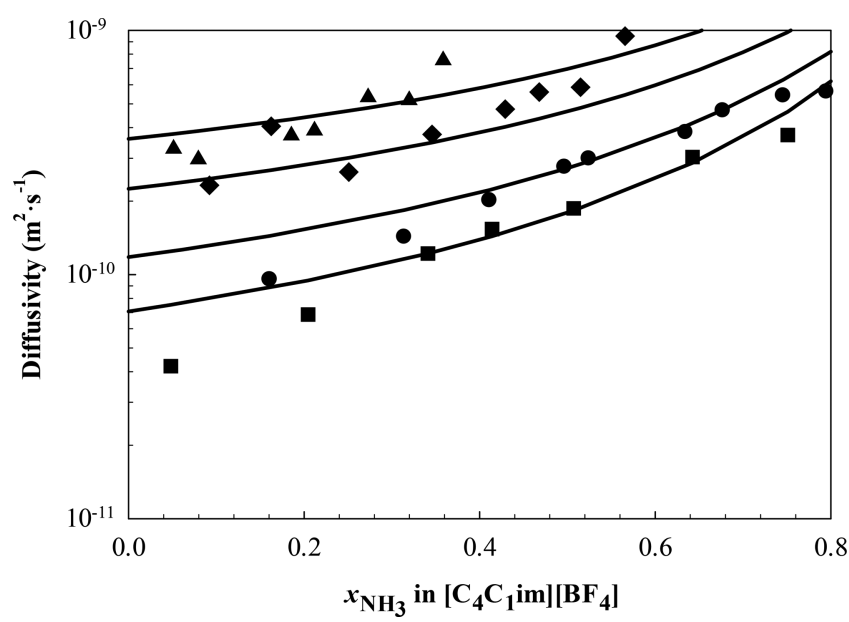

Figure 10. Diffusivity of $\mathrm{NH}_{3}$ in $\left[\mathrm{C}_{4} \mathrm{C}_{1} \mathrm{im}\right]\left[\mathrm{BF}_{4}\right]$. Diffusivity vs composition. Lines represent model calculations, and symbols represent experimental data: (ロ) $283.15 \mathrm{~K}$; (৩) $298.15 \mathrm{~K}$; $323.15 \mathrm{~K} ;(\boldsymbol{\Delta}) 348.15 \mathrm{~K}$.

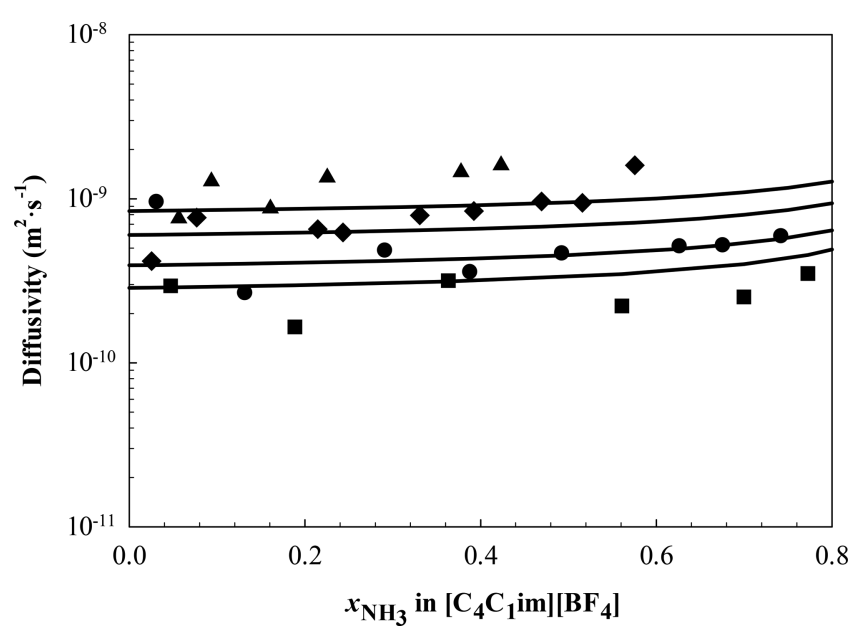

Figure 11. Diffusivity of $\mathrm{NH}_{3}$ in $\left[\mathrm{C}_{2} \mathrm{C}_{1} \mathrm{im}\right]\left[\mathrm{NTf}_{2}\right]$. Lines represent model calculations, and symbols represent experimental data: $283.15 \mathrm{~K} ;(\bullet) 298.15 \mathrm{~K} ;(\diamond) 323.15 \mathrm{~K} ;(\boldsymbol{\Delta}) 348.15 \mathrm{~K}$.

XEMIS gravimetric microbalance. The thermodynamic modeling using the Peng-Robinson equation of state as well as the Non-Random Two Liquid (NRTL) activity coefficient model was in excellent agreement with the experimental data. The Fickian diffusion coefficients for $\mathrm{NH}_{3}$ in imidazolium-based ILs were obtained using a one-dimensional mass diffusion equation and found to be about 3 to 5 times lower than the diffusion of $\mathrm{NH}_{3}$ in water. A semitheoretical Stokes-Einstein equation was used to model diffusivities and to obtain the diffusing radius of $\mathrm{NH}_{3}$ in imidazolium-based ILs. The Stokes-Einstein equation is useful for correlating the diffusivity of $\mathrm{NH}_{3}$ in imidazoliumbased ILs when the thermophysical properties of the solution are known or properly estimated.

\section{ASSOCIATED CONTENT}

\section{S Supporting Information}

The Supporting Information is available free of charge on the ACS Publications website at DOI: 10.1021/acs.iecr.9b00274.

Experimental data reduction; comparison of $P T x$ diagram $\mathrm{NH}_{3}$ and $\left[\mathrm{C}_{4} \mathrm{C}_{1} \mathrm{im}\right]\left[\mathrm{PF}_{6}\right],\left[\mathrm{C}_{4} \mathrm{C}_{1} \mathrm{im}\right]\left[\mathrm{BF}_{4}\right]$, or $\left[\mathrm{C}_{2} \mathrm{C}_{1} \mathrm{im}\right]\left[\mathrm{NTf}_{2}\right]$; name, abbreviation, and structures of the chemical; experimental vapor liquid equilibrium and modeled diffusivity data for $\mathrm{NH}_{3}$ and $\left[\mathrm{C}_{4} \mathrm{C}_{1} \mathrm{im}\right]\left[\mathrm{PF}_{6}\right]$, $\left[\mathrm{C}_{4} \mathrm{C}_{1} \mathrm{im}\right]\left[\mathrm{BF}_{4}\right]$, and $\left[\mathrm{C}_{2} \mathrm{C}_{1} \mathrm{im}\right]\left[\mathrm{NTf}_{2}\right](\mathrm{PDF})$

\section{AUTHOR INFORMATION}

\section{Corresponding Author}

*E-mail: mark.b.shiflett@ku.edu. Tel: +1 785-864-6719.

ORCID ${ }^{\circ}$

Tugba Turnaoglu: 0000-0001-8523-8525

Mark B. Shiflett: 0000-0002-8934-6192

\section{Author Contributions}

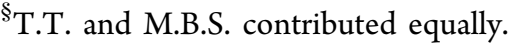

\section{Funding}

This research did not receive any specific grant from funding agencies in the public, commercial, or not-for-profit sectors.

\section{Notes}

The authors declare no competing financial interest.

\section{ACKNOWLEDGMENTS}

The authors would like to thank Katherine McKie, Matt Gee, Mathew Powner, and Luke Wilkinson from Hiden Isochema for their support with the XEMIS gravimetric microbalance. The authors would also like thank to Dr. Elim Myers and Dr. David Griffin for their assistance with the MATLAB programming to calculate diffusion coefficients. The authors also acknowledge the generous donation of ionic liquids from DuPont.

\section{ABBREVIATIONS}

$\mathrm{CO}_{2}=$ carbon dioxide

$\mathrm{H}_{2} \mathrm{O}=$ water

$\mathrm{NH}_{3}=$ ammonia

$\left[\mathrm{C}_{2} \mathrm{C}_{1} \mathrm{im}\right]\left[\mathrm{BF}_{4}\right]=$ 1-ethyl-3-methylimidazolium tetrafluoroborate

$\left[\mathrm{C}_{2} \mathrm{C}_{1} \mathrm{im}\right]\left[\mathrm{PF}_{6}\right]=$ 1-ethyl-3-methylimidazolium hexafluorophosphate

$\left[\mathrm{C}_{2} \mathrm{C}_{1} \mathrm{im}\right]\left[\mathrm{NTf}_{2}\right]=1$-ethyl-3-methylimidazolium bis(trifluoromethylsulfonyl)imide

$\left[\mathrm{C}_{2} \mathrm{C}_{1} \mathrm{im}\right]\left[\mathrm{NO}_{3}\right]=1$-ethyl-3-methylimidazolium nitrate

$\left[\mathrm{C}_{4} \mathrm{C}_{1} \mathrm{im}\right]\left[\mathrm{BF}_{4}\right]=$ 1-butyl-3-methylimidazolium tetrafluoroborate

$\left[\mathrm{C}_{4} \mathrm{C}_{1} \mathrm{im}\right]\left[\mathrm{PF}_{6}\right]=$ 1-butyl-3-methylimidazolium hexafluorophosphate

$\left[\mathrm{C}_{4} \mathrm{C}_{1} \mathrm{im}\right]\left[\mathrm{NTf}_{2}\right]=$ 1-butyl-3-methylimidazolium bis $($ trifluoromethylsulfonyl)imide

$\left[\mathrm{C}_{6} \mathrm{C}_{1} \mathrm{im}\right]\left[\mathrm{NTf}_{2}\right]=$ 1-hexyl-3-methylimidazolium bis $($ trifluoromethylsulfonyl)imide

$\left[\mathrm{C}_{6} \mathrm{C}_{1} \mathrm{im}\right]\left[\mathrm{BF}_{4}\right]=1$-hexyl-3-methylimidazolium tetrafluoroborate

$\left[\mathrm{C}_{8} \mathrm{C}_{1} \mathrm{im}\right]\left[\mathrm{BF}_{4}\right]=$ 1-octyl-3-methylimidazolium tetrafluoroborate

$\left[\mathrm{N}_{111} \mathrm{C}_{2} \mathrm{OH}\right]\left[\mathrm{NTf}_{2}\right]=$ choline bis(trifluoromethylsulfonyl) imide

$\left[\left(\mathrm{HOC}_{2}\right) \mathrm{C}_{1} \mathrm{im}\right]\left[\mathrm{BF}_{4}\right]=1$-(2-hydroxyethyl $)$-3-methylimidazolium tetrafluoroborate

$\left[\left(\mathrm{HOC}_{2}\right) \mathrm{C}_{1} \mathrm{im}\right][\mathrm{DCA}]=1$-(2-hydroxyethyl $)$-3-methylimidazolium dicyanamide

$\left[\left(\mathrm{HOC}_{2}\right) \mathrm{C}_{1} \mathrm{im}\right]\left[\mathrm{NTf}_{2}\right]=1$-(2-hydroxyethyl $)$-3-methylimidazolium bis(trifluoromethylsulfonyl)imide

$\left[\left(\mathrm{HOC}_{2}\right) \mathrm{C}_{1} \mathrm{im}\right]\left[\mathrm{NO}_{3}\right]=1$-(2-hydroxyethyl)-3-methylimidazolium nitrate 
$\left[\left(\mathrm{HOC}_{2}\right) \mathrm{C}_{1} \mathrm{im}\right]\left[\mathrm{PF}_{6}\right]=1$-(2-hydroxyethyl)-3-methylimidazolium hexafluorophosphate

$\left[\left(\mathrm{HOC}_{2}\right) \mathrm{C}_{1} \mathrm{im}\right][\mathrm{SCN}]=1$-(2-hydroxyethyl $)$-3-methylimidazolium thiocynate

$\left[\mathrm{N}_{1}\left(\mathrm{C}_{2} \mathrm{OH}\right)_{3}\right]\left[\mathrm{C}_{1} \mathrm{OSO}_{3}\right]=\operatorname{tris}(2$-hydroxyethyl)methylammonium methylsulfate

$\left[\mathrm{C}_{4} \mathrm{C}_{1} \mathrm{im}\right] \mathrm{Zn}_{2} \mathrm{Cl}_{5}=1$-butyl-3-methylimidazolium chloridezinc chloride

$\left[\mathrm{C}_{2} \mathrm{C}_{1} \mathrm{im}\right] \mathrm{Cu}_{2} \mathrm{Cl}_{5}=1$-ethyl-3-methylimidazolium chloridecopper chloride

$\left[\mathrm{C}_{4} \mathrm{im}\right]\left[\mathrm{NTf}_{2}\right]=$ 1-butyl imidazolium bis(trifluoromethylsulfonyl)imide

$\left[\left(\mathrm{HOOCC}_{3}\right) \mathrm{C}_{1} \mathrm{im}\right]\left[\mathrm{NTf}_{2}\right]=1$-n-butyrate-3-methylimidazoliumbis(trifluoromethylsulfonyl)imide

\section{REFERENCES}

(1) MacFarlane, D. R.; Kar, M.; Pringle, J. M. Fundamentals of Ionic Liquids from Chemistry to Applications, 1st ed.; Wiley-VCH Verlag GmbH \& Co. KGaA: 2017.

(2) Shiflett, M. B.; Maginn, E. J. The Solubility of Gases in Ionic Liquids. AIChE J. 2017, 63 (11), 4722-4737.

(3) Yokozeki, A.; Shiflett, M. B. Ammonia Solubilities in RoomTemperature Ionic Liquids. Ind. Eng. Chem. Res. 2007, 46 (5), 16051610.

(4) Yokozeki, A.; Shiflett, M. B. Vapor-Liquid Equilibria of Ammonia + Ionic Liquid Mixtures. Appl. Energy 2007, 84 (12), $1258-1273$.

(5) Huang, J.; Riisager, A.; Berg, R. W.; Fehrmann, R. Tuning Ionic Liquids for High Gas Solubility and Reversible Gas Sorption. J. Mol. Catal. A: Chem. 2008, 279 (2), 170-176.

(6) Shi, W.; Maginn, E. J. Molecular Simulation of Ammonia Absorption in the Ionic Liquid 1-Ethyl-3-Methylimidazolium Bis(Trifluoromethylsulfonyl)Imide ([Emim $\left.]\left[\mathrm{Tf}_{2} \mathrm{~N}\right]\right)$. AIChE J. 2009, 55 (9), 2414-2421.

(7) Li, G.; Zhou, Q; Zhang, X.; LeiWang; Zhang, S.; Li, J. Solubilities of Ammonia in Basic Imidazolium Ionic Liquids. Fluid Phase Equilib. 2010, 297 (1), 34-39.

(8) Tomida, D.; Tani, Y.; Qiao, K.; Yokoyama, C. Vapor Pressure and Liquid Density of 1-Butyl-3-Methylimidazolium Hexafluorophosphate and Ammonia Mixtures. High Temp. - High Press. 2018, 47 (2), 101-116.

(9) Palomar, J.; Gonzalez-Miquel, M.; Bedia, J.; Rodriguez, F.; Rodriguez, J. J. Task-Specific Ionic Liquids for Efficient Ammonia Absorption. Sep. Purif. Technol. 2011, 82 (1), 43-52.

(10) Bedia, J.; Palomar, J.; Gonzalez-Miquel, M.; Rodriguez, F.; Rodriguez, J. J. Screening Ionic Liquids as Suitable Ammonia Absorbents on the Basis of Thermodynamic and Kinetic Analysis. Sep. Purif. Technol. 2012, 95, 188-195.

(11) Cera-Manjarres, A.; Salavera, D.; Coronas, A. Vapour Pressure Measurements of Ammonia/Ionic Liquids Mixtures as Suitable Alternative Working Fluids for Absorption Refrigeration Technology. Fluid Phase Equilib. 2018, 476, 48-60.

(12) Li, Z.; Zhang, X.; Dong, H.; Zhang, X.; Gao, H.; Zhang, S.; Li, J.; Wang, C. Efficient Absorption of Ammonia with HydroxylFunctionalized Ionic Liquids. RSC Adv. 2015, 5 (99), 81362-81370.

(13) Chen, W.; Liang, S.; Guo, Y.; Gui, X.; Tang, D. Investigation on Vapor-Liquid Equilibria for Binary Systems of Metal Ion-Containing Ionic Liquid $[\mathrm{Bmim}] \mathrm{Zn}_{2} \mathrm{Cl}_{5} / \mathrm{NH}_{3}$ by Experiment and Modified UNIFAC Model. Fluid Phase Equilib. 2013, 360, 1-6.

(14) Chen, W.; Bai, Y. Thermal Performance of an AbsorptionRefrigeration System with $[\mathrm{Emim}] \mathrm{Cu} 2 \mathrm{Cl} 5 / \mathrm{NH} 3$ as Working Fluid. Energy 2016, 112, 332-341.

(15) Shang, D.; Zhang, X.; Zeng, S.; Jiang, K.; Gao, H.; Dong, H.; Yang, Q.; Zhang, S. Protic Ionic Liquid [Bim][NTf2] with Strong Hydrogen Bond Donating Ability for Highly Efficient Ammonia Absorption. Green Chem. 2017, 19 (4), 937-945.
(16) Shang, D.; Bai, L.; Zeng, S.; Dong, H.; Gao, H.; Zhang, S. Enhanced $\mathrm{NH}_{3}$ Capture by Imidazolium-Based Protic Ionic Liquids with Different Anions and Cation Substituents. J. Chem. Technol. Biotechnol. 2018, 93 (5), 1228-1236.

(17) Carvalho, P. J.; Coutinho, J. A. P. Non-Ideality of Solutions of $\mathrm{NH}_{3}, \mathrm{SO}_{2}$, and $\mathrm{H}_{2} \mathrm{~S}$ in Ionic Liquids and the Prediction of Their Solubilities Using the Flory-Huggins Model. Energy Fuels 2010, 24 (12), 6662-6666.

(18) Yokozeki, A.; Shiflett, M. B. Gas Solubilities in Ionic Liquids Using a Generic van Der Waals Equation of State. J. Supercrit. Fluids 2010, 55 (2), 846-851.

(19) Faúndez, C. A.; Díaz-Valdés, J. F.; Valderrama, J. O. Consistency Test of Solubility Data of Ammonia in Ionic Liquids Using the Modified Peng-Robinson Equation of Kwak and Mansoori. Fluid Phase Equilib. 2013, 348 (348), 33-38.

(20) Faúndez, C. A.; Quiero, F. A.; Valderrama, J. O. Correlation of Solubility Data of Ammonia in Ionic Liquids for Gas Separation Processes Using Artificial Neural Networks. C. R. Chim. 2014, 17 (11), 1094-1101.

(21) Sun, G.; Huang, W.; Zheng, D.; Dong, L.; Wu, X. Vapor-Liquid Equilibrium Prediction of Ammonia-Ionic Liquid Working Pairs of Absorption Cycle Using UNIFAC Model. Chin. J. Chem. Eng. 2014, $22(1), 72-78$

(22) Ruiz, E.; Ferro, V. R.; De Riva, J.; Moreno, D.; Palomar, J. Evaluation of Ionic Liquids as Absorbents for Ammonia Absorption Refrigeration Cycles Using COSMO-Based Process Simulations. Appl. Energy 2014, 123, 281-291.

(23) Minnick, D. L.; Turnaoglu, T.; Rocha, M. A.; Shiflett, M. B. Review Article: Gas and Vapor Sorption Measurements Using Electronic Beam Balances. J. Vac. Sci. Technol., A 2018, 36 (5), 050801 .

(24) Shiflett, M. B.; Yokozeki, A. Solubility and Diffusivity of Hydrofluorocarbons in Room-Temperature Ionic Liquids. AIChE J. 2006, 52 (3), 1205-1219.

(25) Lemmon, E. W.; Huber, M. L.; Mclinden, M. O. REFPROP 9.1. NIST Stand. Ref. database 2013.

(26) Chirico, R. D.; Diky, V.; Magee, J. W.; Frenkel, M.; Marsh, K. $\mathrm{N}$. Thermodynamic and Thermophysical Properties of the Reference Ionic Liquid: 1-Hexyl-3-Methylimidazolium Bis[(Trifluoromethyl)Sulfonyl]Amide (Including Mixtures). Part 2. Critical Evaluation and Recommended Property Values (IUPAC Technical Report). Pure Appl. Chem. 2009, 81 (5), 791-828.

(27) Fan, W.; Zhou, Q.; Sun, J.; Zhang, S. Density, Excess Molar Volume, and Viscosity for the Methyl Methacrylate + 1-Butyl-3Methylimidazolium Hexafluorophosphate Ionic Liquid Binary System at Atmospheric Pressure. J. Chem. Eng. Data 2009, 54 (8), 23072311.

(28) Matkowska, D.; Hofman, T. High-Pressure Volumetric Properties of Ionic Liquids: 1-Butyl-3- Methylimidazolium Tetrafluoroborate, $\left[\mathrm{C}_{4} \mathrm{mim}\right]\left[\mathrm{BF}_{4}\right], 1$-Butyl-3-Methylimidazolium Methylsulfate $\left[\mathrm{C}_{4} \mathrm{mim}\right]\left[\mathrm{MeSO}_{4}\right]$ and 1-Ethyl-3-Methylimidazolium Ethylsulfate, $\left[\mathrm{C}_{2} \mathrm{mim}\right]\left[\mathrm{EtSO}_{4}\right]$. J. Mol. Liq. 2012, 165, 161-167.

(29) Fillion, J. J.; Brennecke, J. F. Viscosity of Ionic Liquid-Ionic Liquid Mixtures. J. Chem. Eng. Data 2017, 62 (6), 1884-1901.

(30) Gilbert, W. J.; Shiflett, M. Design and Safety in a New Chemical Engineering Research Laboratory at The University of Kansas. J. Ind. Eng. Saf. 2018, 1 (1), 1-13.

(31) Shiflett, M. B.; Yokozeki, A. Solubility of CO2 in Room Temperature Ionic Liquid $[\mathrm{Hmim}]\left[\mathrm{Tf}_{2} \mathrm{~N}\right]$. J. Phys. Chem. B 2007, 111 (8), 2070-2074.

(32) Kumelan, J.; Kamps, I. P. S.; Tuma, D.; Maurer, G. Solubility of $\mathrm{CO}_{2}$ in the Ionic Liquid $[\mathrm{Hmim}]\left[\mathrm{Tf}_{2} \mathrm{~N}\right]$. J. Chem. Thermodyn. 2006, 38 (11), 1396-1401.

(33) Shiflett, M. B.; Yokozeki, A. Gaseous Absorption of Fluoromethane, Fluoroethane, and 1,1,2,2-Tetrafluoroethane in 1Butyl-3-Methylimidazolium Hexafluorophosphate. Ind. Eng. Chem. Res. 2006, 45 (18), 6375-6382. 
(34) Lopez-Echeverry, J. S.; Reif-Acherman, S.; Araujo-Lopez, E. Peng-Robinson Equation of State: 40 Years through Cubics. Fluid Phase Equilib. 2017, 447, 39-71.

(35) Peng, D. Y.; Robinson, D. B. A New Two-Constant Equation of State. Ind. Eng. Chem. Fundam. 1976, 15 (1), 59-64.

(36) ASPEN Plus (R). Aspen Technology, Inc..

(37) Valderrama, J. O.; Robles, P. A. Critical Properties, Normal Boiling Temperatures, and Acentric Factors of Fifty Ionic Liquids. 2007. https://doi.org/10.1021/ie0603058.

(38) Sandler, S. I. Chemical, Biochemical and Engineering Thermodynamics, 4th ed.; John Wiley \& Sons, Inc.: 2006.

(39) Shiflett, M. B.; Yokozeki, A. Solubilities and Diffusivities of Carbon Dioxide in Ionic Liquids: $[\mathrm{Bmim}]\left[\mathrm{PF}_{6}\right]$ and $[\mathrm{Bmim}]\left[\mathrm{BF}_{4}\right]$. Ind. Eng. Chem. Res. 2005, 44 (12), 4453-4464.

(40) Terasaka, K.; Oka, J.; Tsuge, H. Chem. Eng. Sci. 2002, 57, 3757-3765.

(41) Shiflett, M. B.; Harmer, M. A.; Junk, C. P.; Yokozeki, A. Solubility and Diffusivity of Difluoromethane in Room-Temperature Ionic Liquids. J. Chem. Eng. Data 2006, 51, 483-495.

(42) Jacquemin, J.; Husson, P.; Padua, A. A. H.; Majer, V. Green Chem. 2006, 8, 172-180.

(43) Kammeyer, C. W.; Whitman, D. R. J. Chem. Phys. 1972, 56 (9), 4419-4421. 